\title{
Gender differences in productivity rewards in Italy: the role of human capital
}

\author{
Tindara Addabbo \\ Department of Economics, University of Modena and Reggio Emilia \\ CHILD (Centre for Household, Income, Labour and Demographic Economics), \\ CAPP (Centro di Analisi delle Politiche Pubbliche) and RECent \\ Donata Favaro \\ Department of Economics, University of Padova \\ CHILD (Centre for Household, Income, Labour and Demographic Economics) \\ Stefano Magrini \\ Department of Economics, University of Venice \\ SSE (Advanced School of Economics in Venice)
}

First Draft: June 2010

\begin{abstract}
In this paper we evaluate the gender wage gap component due to differences in characteristics' rewards in Italy. The main focus is on the relationship between human capital characteristics and gender differences in rewards. We propose a methodology that combines the quantile regression analysis with non-parametric procedures for the estimation of the probability density functions of reward differentials in order to evaluate the evolution of the gap due to human capital characteristics. The analysis is carried out on Italian data taken from the latest available cross-section of the European Community Household Panel (2001). Our study suggests that education can be a good productivity signal and helps reduce the range of the gap; furthermore, highly-educated women experience lesser gender-based pay differences as the length of the employment relationship increases.
\end{abstract}

\section{Keywords}

Gender wage gap, human capital, distributional analysis

\section{JEL Codes}

J31, C14, C31

\author{
Address for correspondence: \\ Stefano Magrini \\ Department of Economics \\ Ca' Foscari University of Venice \\ Cannaregio 873, Fondamenta S.Giobbe \\ 30121 Venezia - Italy \\ Phone: (++39) 0412349194 \\ Fax: (++39) 0412349176 \\ smagrini@unive.it
}

This Working Paper is published under the auspices of the Department of Economics of the Ca' Foscari University of Venice. Opinions expressed herein are those of the authors and not those of the Department. The Working Paper series is designed to divulge preliminary or incomplete work, circulated to favour discussion and comments. Citation of this paper should consider its provisional character.

$\begin{aligned} \begin{array}{r}\text { The Working Paper Series } \\ \text { is availble only on line }\end{array} & \begin{array}{l}\text { Department of Economics } \\ \text { Ca’ Foscari University of Venice }\end{array} \\ \text { (www.dse.unive.it/pubblicazioni) } & \text { Cannaregio 873, Fondamenta San Giobbe } \\ \text { For editorial correspondence, please contact: } & 30121 \text { Venice Italy } \\ \text { wp.dse@unive.it } & \text { Fax: ++39 041 2349210 }\end{aligned}$




\section{Introduction}

Empirical studied conducted in a large number of countries have demonstrated that gender wage gaps may be largely attributed to differences between men and women in the rewards to their productive characteristics and not to differences in such characteristics. ${ }^{1}$ The most recent analyses, which evaluate the distributions of wage gaps, highlight furthermore how the extension of such a gap changes with the variations in women's wage levels. The results of these studies are country-specific, and it is difficult to draw general conclusions, yet we may say, in the vast majority of cases, that a greater incidence of the gap may be found with regard to skills in correspondence with the higher levels of pay, characterising the presence of glass ceiling patterns (Albrecht et al., 2003; Albrecht et al., 2004; Arulampalam et al., 2007). However, there are also numerous cases of countries in which a greater gap may be found in correspondence with lower levels of pay and, therefore, with entrance-level working profiles, or ones characterised by a low level of skills; here we might cite the results obtained by De la Rica et al. (2008) on their sample of workers with low levels of education.

In the light of these results, in this paper we analyse the gender gap due to the differences in the incidence of certain characteristics in Italy, with the specific aim of verifying to what degree human capital characteristics -

\footnotetext{
${ }^{1}$ The main contribution of the traditional Oaxaca and Blinder approach (Oaxaca, 1973; Blinder, 1973) can be summarised with the idea that the wage gap can be decomposed into two terms: a first term representing productivity differences explained by individual characteristics, and a second term explaining earnings gaps in terms of differences in the remuneration of those characteristics.
} 
education and experience - are responsible for the distribution of the gap. More specifically, the aim of this article is twofold: to verify whether the dichotomy between highly- and low-educated workers (European Commission, 2005) really does imply different patterns of gender pay differences in terms of rewards, and to find out whether any other human capital characteristics are affecting the pattern of the gap.

Most of the literature regarding the Italian gender wage gap and its components is based mainly on the traditional Oaxaca and Blinder method (Oaxaca, 1973; Blinder, 1973) and evaluates the average level of the gap and its components. Addis and Waldmann (1996), using the 1989 crosssection from the Italian Survey on Household, Income and Wealth (SHIW), estimate an average level of the unexplained component to the wage gap as equal to $13 \%$. By using the same survey, but on the year 1991, Flabbi (1997) evaluates a wage gap due to differences in rewards that ranges between 8 and 12 percentage points, depending on the population of reference and on the econometric method employed - either OLS or Instrumental Variables. ISTAT (2005) estimates an average component of the "unexplained" gender gap in gross hourly earnings equal to 11 percentage points.

Recently, a couple of works have proposed studying the gender wage gap taking distributional aspects into account. Addabbo and Favaro (forthcoming) evaluate the extent of the Italian gender wage gap and its components based on different educational levels by using the quantile estimation procedure and the Machado and Mata (2005) methodology to derive marginal distributions of predicted and counterfactual female wages. 
They show that low-educated women suffer a higher unexplained wage gap than their highly-educated colleagues across the whole distribution; however, while low-educated female wages appear not to be affected by either a sticky-floor effect or a glass-ceiling pattern, there is some evidence of a glass-ceiling pattern for highly-educated females.

Favaro and Magrini (2008), taking their lead from the contribution made by Jenkins (1994), develop a non-parametric procedure (based on OLS coefficient estimates) to evaluate the probability distribution of the "unexplained" part of the wage gap for young females in North-eastern Italy. $^{2}$ Their results show that the component of the wage gap due to differences in rewards based on human capital characteristics increased throughout the $1990 \mathrm{~s}$ across the whole distribution, and that it was more accentuated among females earning the highest wages: in general, highlyeducated women suffer lower levels of difference in returns to human capital characteristics than low-educated females, yet they experience much higher increases in the gap as they move towards the top of the distribution. Furthermore, the accumulation of other human capital characteristics, such as experience and tenure in the firm, does not help them to narrow the wage gap.

The present paper takes on some of the suggestions to be found in the most recent literature in order to study the distribution of the gap due to the incidence of human capital characteristics and the relationship between such distribution and these characteristics. To this end, we propose using the quantile estimate procedure and the methodology proposed by

\footnotetext{
${ }^{2}$ The same method is applied in the present article and it will be discussed in the methodological section of the paper.
} 
Machado and Mata (2005) in order to obtain marginal distributions from the sample data. However, our study suggests using a different tool for the analysis of the distribution of the gap. Instead of comparing the quantile values of the marginal distributions of theoretical and counterfactual retributions, firstly we obtain the marginal distribution of the gap from these values, as suggested by Jenkins (1994); we then use the marginal distributions of the productive characteristics of women to put together the distributions of the gaps based on the distributions of human capital characteristics. This procedure allows us to represent clearly and efficiently the relationship between human capital characteristics, the size of the gap and the likelihood of its existence; furthermore, it also makes it possible to identify any fields in which a gap may be found in women's favour.

Our analysis is based on a sample of employed workers, 15-65 years old, working full time, selected from the last available wave (year 2001) of the European Community Household Panel (ECHP). We focus exclusively on employed people primarily because of the lack of satisfactory information on self-employed workers (especially on earnings and hours of work), which makes any comparison or unified treatment with employed workers rather difficult.

The paper is organised as follows. In Section 2 we describe the methodological approach adopted and in Section 3 we describe the dataset and provide some descriptive statistics. Earnings function estimates and the analysis of the wage gap distributions are discussed in Section 4. Section 5 deals with the conclusions. 


\section{A distributional approach to the analysis of gender differences in characteristics’ rewards}

The most recent literature on gender wage differentials has focused on the analysis of the breadth of the gap in correspondence with different wage levels, while at the same time adopting the traditional breakdown of the wage gap in terms of the component explained by gender differences in the characteristics and in that due to differences between the two sexes in the incidence of these differences, as suggested by the works published in the early ' 70 s by Oaxaca (1973) and Blinder (1973). In this literature, the Machado and Mata (2005) method is generally applied, which makes it possible to reconstruct the marginal differences in theoretical and counterfactual earnings, based on coefficients estimated in correspondence with the various deciles of wage distribution (in keeping with Koenker and Bassett's 1982 method of quantile regression). This procedure will also be adopted in the present paper in which, as outlined above, we shall concentrate exclusively on the gap due to differences in earnings based on productive characteristics.

On the other hand, the distributional approach implemented here diverges from that used in the above-mentioned literature, insofar as while in those works the gap due to the rewards to productive characteristics is evaluated as a difference between the decile levels of the marginal distributions of the theoretical and counterfactual earnings as considered separately, in the present study we evaluate the gap through the construction of a single marginal distribution: that of the difference. As well as allowing for the evaluation of the probability distribution of the gap values in relation to 
wage levels, this methodology provides several other possibilities of further analysis compared to the tools adopted so far, for it allows us to study the distribution of the gap also in relation to the distribution of productivity characteristics. As a matter of fact, we may associate the marginal distributions of the characteristics as observed to the marginal distribution of the gap, based on the various productivity components. In our case, we shall focus on the relationship between the gap and the characteristics of human capital.

We proceed to by estimating decile coefficients for the explicative variables, using the quantile regression method (Koenker and Bassett, 1982; Buchinsky, 1998) which consists in evaluating the rewards to productive characteristics by allowing for different values in correspondence with any chosen decile (or quantile) of the wage distribution.

Given the covariates vector $z$, the quantile regression allows us to estimate $\mathrm{Q}_{\theta}(\omega \mid z)$, corresponding to the $\theta$-th quantile of the distribution of the $\log$ wage $(\omega)$, at any $\theta \in(0,1)$. The quantile regression model is assumed to be linear:

$$
\omega=\mathrm{z}^{\prime} \beta_{\theta}+\mathrm{u}_{\theta}
$$

where $\omega$ is the $\log$ of hourly wages ${ }^{3}$ and $\beta_{\theta}$ is a vector of coefficients: the quantile regression coefficients. The distribution of the error term $u_{\theta}$ is unspecified and it is simply assumed that $Q_{\theta}\left(u_{\theta} \mid z\right)=0$. The estimated values

\footnotetext{
${ }^{3}$ The wage rate is calculated following the procedure generally exploited when using the ECHP dataset: we divide (gross) monthly current wage and salary earnings from the main job by the number of weekly hours worked (in the main job), multiplied by the monthly standard number of weeks (4.3).
} 
of the $\theta$-th quantile of the $\log$ wages, conditioned to covariates $z$, is equal to: $Q_{\theta}(\omega \mid z)=z^{\prime} \hat{\beta}_{\theta}$. For any $\theta \in(0,1), \beta_{\theta}$ can be estimated by minimising in $\beta_{\theta}$ the following expression:

$$
n^{-1} \sum_{i=1}^{n} \varrho_{\theta}\left(\omega_{i}-z_{i}^{\prime} \beta_{\theta}\right)
$$

where:

$$
\rho_{\theta}\left(u_{i}\right)=\left\{\begin{array}{ccc}
\theta u_{i} & \text { for } & u_{i} \geq 0 \\
(\theta-1) u_{i} & \text { for } & u_{i}<0
\end{array}\right.
$$

The vector of coefficients $\beta_{\theta}$ can be obtained by estimating each equation either separately or simultaneously. The simultaneous procedure allows us to obtain an estimate of the entire variance-covariance matrix of the estimated coefficients, which is necessary to implement tests of interquantile differences in the estimated coefficients. ${ }^{4}$ Following the procedure above described, we obtain the rewards to worker characteristics, by specifying different models for females and males; thus, we obtain a vector of estimated quantile coefficients for female workers, $\hat{\boldsymbol{\beta}}_{\boldsymbol{\theta}_{\boldsymbol{f}}}$ and a vector of estimated quantile coefficients for male workers, $\hat{\boldsymbol{\beta}}_{\boldsymbol{\theta}_{\boldsymbol{m}}}$.

Let us bear in mind that the component of the gap due to differences in earnings because of productivity characteristics (the evaluation of which is the focus of this paper) is given by the difference between the theoretical earnings that the woman receives given the incidence of their own characteristics as attributed to women on the basis of their productivity

\footnotetext{
${ }^{4}$ The bootstrapping procedure allows us to test whether coefficients of different quantile regressions are significantly different.
} 
characteristics and the counterfactual earnings, i.e. the wages that women might receive were their characteristics to be remunerated at the same level as men. Such a difference is given by the outcome of the productive characteristics of women given the difference in the remuneration coefficients between men and women.

In order to obtain the marginal distribution of such a gap, once the coefficients of men and women's characteristics have been estimated, we firstly calculate their difference, for each characteristic, in correspondence with each decile $\theta$. Then, in order to recreate the marginal distribution of the gap, we carry on following the Machado and Mata (2005) procedure, or the simplified version thereof as set out by Albrecht et al. (2003), ${ }^{5}$ which consists in recreating a random distribution, based on our sample. This may be obtained through the repeated extraction (with reinsertion) of women from our sample, to whom we then apply the corresponding difference of the estimated coefficients.

More in detail, we proceed by choosing a decile $\theta$ and taking a random sample from the female database. Then, we construct the gap due to differences in characteristics' rewards by multiplying the vector of characteristics $\boldsymbol{z}_{f}$ of the selected individual by the raw vector of differences in estimated coefficients $\left(\hat{\boldsymbol{\beta}}_{\boldsymbol{\theta}_{\boldsymbol{m}}}-\hat{\boldsymbol{\beta}}_{\boldsymbol{\theta}_{f}}\right)$. We repeat that operation $\mathrm{N}=100$ times. Then we repeat the procedure for every decile, ending up with the estimated marginal distribution of female gaps due to differences in characteristics' rewards. The same procedure is adopted to construct the

\footnotetext{
${ }^{5}$ Albrecht et al. (2003) adopt a simplified version of the methodology proposed by Machado and Mata in a mimeo that was later published in the Journal of Applied Econometrics (Machado and Mata, 2005).
} 
marginals of the characteristics of human capital that will be used nonparametrically to estimate the probability distributions of the conditional gaps with regard to the various characteristics.

Having constructed the marginal distributions of the gap due to differences in characteristics" rewards (referred to as the "wage gap" from here onwards) and the marginal distributions of characteristics, we then estimate conditional density functions non-parametrically in order to evaluate the probability of the occurrence of different levels of wage gap, based on predicted earnings and on different observed characteristics.

Let us use $F(d)$ to denote the distribution of the wage gap and $F(x)$ to denote the distribution of a variable $x$ that we will explain later on. Next, suppose these distributions can be described by density functions, which can be indicated with $f(d)$ and $f(x)$ respectively. What we are interested in is the relationship between the two distributions or, equivalently, between the two density functions; this can be simply written as

$$
f(d)=\int_{0}^{\infty} f(d \mid x) f(x) d x
$$

where $f(d \mid x)$ is the density of the wage gap conditional on any level $\mathrm{x}$ for the factor or characteristic of interest.

From an operational point of view, we obtain an estimate of $f(d \mid x)$ in three steps. First, we non-parametrically estimate the joint probability density function of $\mathrm{d}$ and $\mathrm{x}$, using a bivariate product kernel density estimator:

$$
\hat{f}(d, x)=\frac{1}{n h_{d} h_{x}} \sum_{i=1}^{n} K\left(\frac{d-d_{i}}{h_{d}}, \frac{x-x_{i}}{h_{x}}\right)
$$


where $K(\cdot)$ is the kernel function, while $h_{d}$ and $b_{x}$ are the kernel bandwidths. ${ }^{6}$ Next, we obtain an estimate of the marginal probability density function $f(x)$ by numerically integrating the joint density function with respect to the wage gap. ${ }^{7}$ Finally, we obtain the estimate of $f(d \mid x)$, the density function of the pay differential, conditional on estimated earnings or any characteristic of interest, by dividing the joint density by the marginal one: ${ }^{8}$

$$
\hat{f}(d \mid x)=\frac{\hat{f}(d, x)}{\hat{f}(x)}
$$

The incidence and direction of the wage gap may thus be studied by directly analysing the shape of the three-dimensional plot of the conditional density estimate and of the corresponding two-dimensional contour plot. At this point, it should be noted that not all characteristics can be measured in a continuous space. In such instances, as is the case of the level of education and the experience accumulated within the firm, ${ }^{9}$ rather than providing a direct estimate of the density function of the wage gap conditional on the values of the discrete variable, we follow an alternative approach. Suppose that the characteristic of interest presents $l$ levels and group individuals in the sample accordingly so as to obtain $l$ subsets. Then, for each subset we estimate the density function of the wage

\footnotetext{
${ }^{6}$ To estimate the joint density function, we use a Gaussian product kernel with bandwidths chosen optimally according to Silverman (1986).

${ }^{7}$ In this, we follow the procedure originally suggested by Quah (1996). As an alternative, the marginal distribution is often estimated directly using a univariate kernel. However, as pointed out by Overman and Ioannides (2001), the two estimators have identical asymptotic statistical properties, and produce very similar results in practice.

${ }^{8}$ Under regularity conditions, this represents a consistent estimator for conditional distribution (Rosenblatt, 1971; Silverman, 1986; Quah, 1996; Chen, Linton and Robinson, 2001).

${ }^{9}$ As we shall explain later in the paper, ECHP data do not contain a continuous variable measuring tenure and we are forced to represent experience accumulated within a firm as a set of dummy variables.
} 
gap conditional on estimated earnings (or on any other meaningful continuous variable) as in Eq. (6). Each of these estimates therefore shows the distribution of wage differentials conditional on estimated earnings, for a given level of the characteristic. Moreover, direct comparisons between estimates obtained for different levels of the characteristic indicate how the conditional distribution is affected by changes in the level of the characteristic.

As for the interpretation of the results, absence of gender wage gaps is represented by a concentration of the probability mass along the line running parallel to the axis of the conditioning variable and in correspondence to a level of wage gap equal to zero, while evidence of wage gaps against (in favour of) female workers is signalled by a probability mass lying above (below) this horizontal line.

\section{The dataset}

The analysis is carried out on a sample of employed workers aged between 15 and 65 selected from the 8 th wave $^{10}$ of the European Community Household Panel (ECHP); we do not include the group of self-employed workers due to the unsatisfactory level of information on their earnings and hours of work, which makes the comparison with employed workers rather difficult, and nor do we include part-time workers. ${ }^{11}$

The model we estimate assumes that the wage level is affected by individual characteristics and other characteristics linked to the demand

\footnotetext{
${ }^{10}$ This is the most recent available wave, referring to the year 2001.

${ }^{11}$ Given the unbalanced presence of Italian women and men in part-time work, we prefer to exclude parttime workers from the sample, in keeping with most of the literature on the analysis of wage differentials.
} 
side of the labour market, such as the size of the firm, the sector of activity, the type of contract and the regional context of reference. Regarding individual characteristics, the ECHP provides information on several factors of significant interest in evaluating individual human capital endowment; in particular, we may access data on education, the starting year of working activity, the number of years of experience in the present firm, the level of supervisory responsibility in the current job and the professional category. Furthermore, the survey supplies some key demographic and socioeconomic characteristics of the individuals, such as age, sex, marital status and family composition.

Following Addabbo and Favaro (forthcoming), who show how Italian female to male wage differentials in Italy strongly depend on workers' education attainment, and that the trend of the gap across the female wage distribution is rather different between highly and low-educated women, we separate workers with a compulsory educational level (low-educated) from those with a higher level diploma (highly-educated). We chose this categorisation because it fits the structure of the Italian educational system and the related occupational opportunities. In Italy, compulsory schooling sums a total of up to eight years, subdivided in two cycles: the first, up to five years of primary school (the so called "scuola elementare") and the second, three years of lower-secondary school ("scuola secondaria inferiore"). Individuals end the compulsory cycle, and decide whether to keep on studying when they are between 13 and 14 years old. If they decide to stay in school and enter the so-called upper stage of secondary education ("scuola secondaria superiore"), they can choose between 
different educational paths, some more technical-mathematical and other more humanistic. Whatever the case may be, if they complete the whole cycle of studies, they are allowed to enter university. This educational structure leads to quite a strong categorisation in the labour market between individuals with a compulsory educational level and those with a higher degree of study. As Table A1 shows, ${ }^{12}$ the former are mainly forced to enter low-skilled operative and blue-collar employment while the latter have access to clerical occupations and, if they have a university degree, may have better access to managerial positions.

In light of these considerations, we believe it appropriate to classify workers with a compulsory level of education as low-educated, and individuals with at least a post-compulsory school diploma as highlyeducated. In international terms, this corresponds to distinguishing between educational levels ISCED 0-2 and ISCED 3-7. Given this categorisation, the information available in the ECHP dataset makes it possible to define some control dummies for individuals with a third level of education (ISCED 5-7) that will be included in the estimates related to the highly-educated group.

As for other human capital characteristics that we check for in the regression process, we measure two different types of human capital acquired after the school: general experience and firm-specific experience. The ECHP collects information on the year of an individual's first entering the labour market; by using that information, we construct the number of years of potential experience any worker could have accumulated since

\footnotetext{
${ }^{12}$ All descriptive statistics and results reported in the paper are calculated on samples of 15-65 year-old individuals, employed full-time.
} 
her/his first working experience. Some caution is generally needed when using such a "theoretical" measure of experience in analyses on wages and gender differentials: the measure may not correspond to the effective years spent in the labour market because it does not take into account periods of absence from the labour market, owing to unemployment, inactivity, or simply illness or parenthood. If this occurred, potential experience would overestimate the real number of years of working activity. In general, such a measurement problem arises both for males and females; however, as the empirical evidence suggests, the problem is more serious for females, due to interruptions connected with maternity. We try to address the issue by adding, among the explicatory variables, the interaction of potential experience with the number of children. If it is true that having children implies some penalty in terms of experience, we should detect a negative impact of that variable on the level of wages and thus solve the problem at least partially.

We complete the information on individuals' human capital endowment by taking firm-specific experience into account, e.g. the period of permanence in the current firm, which we will label "tenure". Unfortunately, the European survey does not provide the precise number of years of tenure for all workers, but only for those that have been working in the same firm for less than fifteen years. As a consequence, we are not able to know the exact period of permanence when workers have been in the present firm for more than fifteen years. So, in order to normalise information, we are forced to use dummy variables that capture the effect of different periods of time: we construct four different intervals corresponding to a period of 
tenure up to five years, between five and ten years, between eleven and fifteen years and longer than fifteen years.

Since the dataset contains information on the occupational content of jobs (principal activity performed and degree of responsibility), we complete the empirical model including controls for those aspects, whose relation to wage rates can be substantial ${ }^{13}$. The inclusion of controls by occupational categories $^{14}$ is particularly important; indeed, the segregation of women into certain occupations can account for a sizable fraction of the wage gap, as recently shown in a work by Baynard et al. (2003). Adding controls on the degree of responsibility ${ }^{15}$ the employee declares to have in her/his job is relevant in the light of the fact that responsibility is normally remunerated, and not considering it could affect the estimation results on human capital characteristics and the evaluation of the components of the wage gaps. That said, we are aware that not having a supervisory role in the job could, in the female case, be a result of an employer's discriminatory attitude.

We complete the model by adding controls for the length of the contract distinguishing permanent employment from fixed-term, short-term

\footnotetext{
${ }^{13}$ We also include dummies for macro-economic sectors.

${ }^{14}$ We used 16 occupational categories, taking "elementary occupations in sales and services" as a benchmark.

${ }^{15}$ The questionnaire asks the individual if s/he supervises or co-ordinates the work of any personnel and, if so, whether s/he has any say in their pay or promotion. On the base of those questions, the database defines a categorical variable with value zero if the worker declares not to have any supervisory or coordination position in the business, value 1 if s/he answers positively to the first question, but negatively to the second, and value 2 if the interviewee answers positively to both questions. On the basis of this information, we construct two dummies to be included in the empirical model: one for individuals with an intermediate degree of supervision, and a second for those with a higher supervisory role.
} 
contracts and from other types of employment contracts. ${ }^{16}$ Finally, we account for the size of the firm and for regional factors.

A summary of the statistics of the variables used in the estimates is to be found in the Appendix (Table A2). In average terms, the raw log wage gap is against female workers, for both educational levels, and it is significantly higher in the case of low-educated than highly-educated women: highlyeducated women suffer, on average, an $8 \%$ gap, against a $14 \%$ one in the case of the low-educated. ${ }^{17}$ With regard to human capital characteristics, we may observe a slightly higher proportion of women than men with a tertiary educational level. Since the sample includes employees up to 65year-old, this figure confirms the substantial educational upgrading of young females. On the other hand, as to other human capital characteristics accumulated after formal education (e.g. experience and tenure), men register the highest average levels.

A few other remarks on sample characteristics are interesting to note. Firstly, independently of the educational level, women are more concentrated in small firms than men are, and are more likely to be employed with fixed-term or short-term contracts. However, being highlyeducated facilitates access to permanent occupations: the frequency of temporary contracts decreases when workers, either male or female, are highly-educated.

\footnotetext{
${ }^{16}$ In the category "other type of contract", we summarise the categories defined by the ECHP as "casual work with no contract" and "other arrangement".

${ }^{17}$ Throughout the paper, for the sake of simplicity, we will refer to the extent of log wage gaps (at different deciles) as percentages, although we are aware that, for example, a 0.15 log wage difference corresponds to a $16.18 \%$ gap.
} 
Accessing supervisory positions is rather uncommon among low educated employees, as only $3 \%$ of females and $4.7 \%$ of men with this background have a high supervisory role in their occupations. The proportion is slightly higher $(7.6 \%$ for females and $10 \%$ for males) when considering only an average degree of supervision. The difference by sex in accessing positions of responsibility is substantial when we look at highly educated employees: ${ }^{18}$ only $6 \%$ of women, compared to $16.4 \%$ of men, exercise a significant supervisory role, while $12.4 \%$ of women and $20.5 \%$ of men obtain an average degree responsibility.

\section{The distributional analysis}

Before moving on to the main focus of our study - the distributional analysis - let us spend a few words on the estimation results that are reported in the Appendix. According to these results, there appear to be interesting differences between the rewards for the characteristics of workers with different educational levels, and between females and males (Tables A3 and A4), in particular with reference to human capital characteristics.

As for highly-educated workers, we might occupy a few lines briefly commenting on the estimated results. For this group of workers, the type of human capital accumulated after formal education plays a role of great relevance in explaining wage upgrading by gender; in line with the evidence emerging in the literature on gender wage differentials carried out in other countries and with the few studies on Italy, we find that male wages are

${ }^{18}$ This is consistent with the existence of vertical occupational segregation by gender in Italy (Rosti, 2006). 
more sensitive to general experience - accumulated in the labour market than to specific human capital built up in the firm where working at present; on the contrary, female wage upgrading strongly depends on specific experience. Going into detail, the return to general experience is positively significant for men, even though decreasing with the rise of the wage rate and insignificant at very high wage levels. On the other hand, it is only slightly significant for women, and only in correspondence to the first decile of the distribution and around the median value, its value furthermore being half that of men.

Returning to the rewards for specific experience, i.e. the variable "tenure", our results appear to outline the existence of different models of economic reward by gender. Male workers are able to obtain a gradual increase in wages as the period of permanence in the firm increases, and that upgrading is recognised as from short periods of tenure. On the contrary, females achieve statistically significant rewards if the period of permanence in the firm becomes particularly long, precisely longer than ten years; indeed in that case, returns are higher than what men receive. Likewise, if male workers have supervisory roles in the firm, they get incremental rewards as coordination tasks become more relevant. On the other hand, female workers with supervisory positions are able to achieve economic gratification for that position only if they get the highest degree of coordination or supervision of any personnel, corresponding to having a say in their own pay or promotion.

The incidence of acquired human capital on the labour market after a period of schooling does not appear to substantially affect the retribution 
levels of low-educated workers. General work experience loses almost all its significance when explaining wage levels, if not with regard to very low hourly wages (to be found in the first deciles of the distribution), both among men and women. On the other hand, unlike what occurs in the group of the most highly-educated males and females, specific experience gained in the firm in which the individual was working at the moment of the survey guarantees wage upgrading only to male workers who have been in the company for at least 15 years. Likewise, we may say that supervising roles do not guarantee economic recognition for women, unless the coordination tasks are of a certain entity, in which case the remuneration may be high. Male workers, on the other hand, are attributed wage upgrades both when the responsibility tasks are intermediate and at the highest levels; in the first case the incidence of a supervising role is significant in correspondence with intermediate wage levels, while in the latter case, the upgrading is recognised in correspondence with higher levels of retribution.

We may now move on to the investigation of the wage gap based on the distributional approach. Before proceeding, two things must be clarified in order to facilitate the interpretation of the results. First of all, the wage gap is measured here as the difference of log predicted and counterfactual wages, expressed in percentage points. Secondly as for the interpretation of the figures, the lines reported in all contour plots are percentage contour lines. In particular, the value adjacent to each line indicates the percentage of the density volume that lies above the line itself (on the vertical axis of the three-dimensional plot). So, areas enclosed within a low-value line are 
in fact associated with a high conditional probability level and thus enable us to identify the peaks of the conditional probability density.

\section{[Figure 1 around here]}

The first step is represented by the study of the probability of occurrence of a wage gap, conditional on estimated earnings for different levels of education. In particular, Figure 1 shows both the three-dimensional and the contour plots of the estimates corresponding to low- (upper panes) and highly- (lower panes) educated females. Several important features emerge. All estimates suggest the existence of substantial gender differences in characteristics' rewards to the disadvantage of female workers, as a large share of the conditional density mass is positioned above the horizontal line for both levels of education. However, there appears to be considerable diversity between education levels with respect to the variability of the phenomenon along the range of estimated earnings. To see this, let us focus on the 0.9 contour line. In the case of low-educated females, we may notice that the variability of the wage gap is extremely high for low earning levels, and decreases as earnings increase. In contrast, the probability mass for highly-educated females appears to be more homogenously distributed along the range of earnings, and in correspondence to lower (relative) wage gap levels. In addition to this, the extent of the gap decreases as estimated earnings increase for female workers with a low educational level, as may be inferred from the fact that the corresponding density mass is downward sloping. In contrast, such a 
negative relationship between differences in rewards to characteristics and hourly wages is not so evident for highly-educated females; as a matter of fact, the wage gap for women in the highly-educated group appears to improve only at very low and high wage levels. In brief, the behaviour of the distribution seems to highlight a great disadvantage for low-educated women as they enter the labour market, and which is gradually reduced (both in terms of range and variability) with the increase in wages, to the point of reaching negative values in correspondence with higher wage levels, entailing an incidence-based gap in women's favour. In actual fact, the disadvantage corresponding to very low wages may also be found among highly-educated women; however, in percentage terms, this disadvantage is lesser than that of the low-educated women, and seems to regard a subgroup independent of the overall distribution. in fact, this appears to be positioned around more or less stable differential values, and implies a slight reduction in the wage gap only in the light of the higher (hourly) wage levels.

The model that emerges from this analysis, therefore, is slightly different from that found (once again with regard to Italy) by Addabbo and Favaro (forthcoming) using the comparison procedure of the decile distribution of theoretical and counterfactual wages considered separately. It could not be otherwise, since the methodologies feature fundamental differences, i.e. in the very construction of the way the gap is distributed. However, our results do seem to reconfirm the findings of the Spanish case (de la Rica et al., 2008) at least with respect to the group of low-educated female 
workers; in fact, also in Spain, a differential may be noted which decreases steadily with the increase of hourly wage levels.

An assessment of the incidence of the wage gap may be performed by calculating the share of the volume of the estimated conditional density that lies above the horizontal line. Such a measure can thus be interpreted as the cumulative conditional probability of wage differences against female workers. Hence, a value higher (lower) than $50 \%$ may be seen as evidence of wage gaps against (in favour of) female workers. Additionally, making use of horizontal lines with a positive intercept, we may decompose this measure according to the incidence of the gap relative to estimated earnings. Looking now at the results reported in Table 1, we may then see that the cumulative probability of unexplained wage gaps against women is higher for highly-educated females than for low-educated ones (equal to $85.80 \%$ and $67.38 \%$ respectively). Moreover, the cumulative probability of wage gaps against women ranging between 0 and $5 \%$ is equal to only $19.67 \%$ for low-educated, compared to a value of $39.60 \%$ for highlyeducated; these percentages decrease respectively to $18.02 \%$ and $31.14 \%$ if we evaluate the cumulative probability of wage gaps between $5 \%$ and $10 \%$ of predicted wages. Finally, as we move to wage differentials higher than 10 percentage points, we find that the cumulative probability for highlyeducated females (equal to 15.06 percentage points) is much lower that the cumulative probability for lowly-educated women (amounting to $29.70 \%$ of predicted wages).

We may conclude this initial evaluation of the distribution of the wage gap between differently educated workers by saying that, in general, lowly- 
educated females are penalised more than highly-educated women in terms of characteristics' rewards, compared to males with the same educational levels. However, females with low educational levels are able to substantially upgrade their rewards as they move from low to high wage levels, and experience unexplained wage differentials in their favour.

As pointed out in the methodological section, the procedure we implement allows us to evaluate the distribution of the wage gap - conditional to the distribution - of any individual characteristic. Whenever the productive attribute of interest can be measured in a continuous space, we can directly estimate the probability of wage differentials conditional to the values of the chosen characteristic. So, Figure 2 reports the estimated conditional density functions of the pay gap with respect to the years of experience accumulated in the labour market prior to the present occupation, again distinguishing between low and high educational levels. While the conditional densities are predominantly positioned in the part of the plane corresponding to wage differences against female workers both for high and low levels of education, the variability of the gap appears to be sensibly wider for low-educated females. Looking at the position of the density crests in the three-dimensional plots, it appears that a wage gap of approximately $5 \%$ of the estimated earnings is the most likely outcome at all levels of experience and education.

While the variability of the gap is much higher for low-educated women, we note traces, of a glass ceiling effect, but only in the case of highly educated women; in fact, with the growth of experience gained on the labour market, the distribution of the gap for educated women seems to 
shift towards slightly higher differential levels. However, in general, work experience does not seem to play a significant role in the behaviour of the gap.

\section{[Figure 2 around here]}

Finally, let us turn to the results that may be drawn from the analysis of the relation between wage gaps and workers' tenure. However, before looking at the estimates, it must be noted that here we have chosen to follow a different way of partitioning the period of permanence within a firm from that adopted while estimating wage functions. On that occasion, we constructed four separate dummy variables - corresponding to tenure levels of between 0 and 5 years, 6 and 10 years, 11 and 15 years, and more than 15 years - and excluded the first from the analysis. Here, in order to make use of all available observations and to distribute them as homogenously as possible, we grouped the dummies into two simple categories. So, while Figure 3 reports the estimated density function of the wage gap conditional to estimated earnings for female workers with a tenure of 10 years or less, Figure 4 shows the corresponding estimate for workers with a tenure of 11 years or more.

The general picture that emerges from these Figures is quite unambiguous.

Once more, we find significant evidence of a substantial degree of pay differences against female workers given that most of the estimated densities lie well above the horizontal line. Besides, through these estimates we may further qualify one of the features noticed in the analysis 
of Figure 1. There, we noted the existence of a negative relationship between the extent of the wage gap and the level of predicted earnings for lowly-educated females. Looking at the upper panes of Figures 3 and 4, we may see that this feature is substantially confirmed for both tenure categories. At the same time, the lower panes of the figures also confirm the absence of such an evident negative relationship for highly-educated workers; in this case we may observe that, unlike what occurs in the overall distribution (Figure 1, lower pane), the area that represents $50 \%$ of the probability distribution follows an initially falling trend which then rises slightly starting from an hourly wage of around 3 Euros, suggesting the presence of a certain glass ceiling effect.

However, other interesting features may be recognised through a more detailed comparison between the two tenure categories. Concentrating on the plots for low educational levels, we may observe that $50 \%$ of the probability mass of workers with the highest tenure period is concentrated on wage gap levels lower than $10 \%$. We may clearly notice that with the rise of tenure, the probability of experiencing extremely high wage gaps (around 30\%) becomes significant for women with very low wage levels; on the other hand, the proportion of the probability mass at negative values of the wage gap (the gap in favour of women) sharply reduces. In brief, low-educated women generally achieve substantial improvements (in the wage gap) as their wages increase; however, this upgrading contracts as their permanence in the firm becomes longer.

This result is verified also in the case of highly-educated workers. Indeed, we may note that, while female workers with tenure periods of 10 years or 
less are characterised by pay gaps in their favour for relatively high levels of estimated earnings (Figure 3, lower panes), this phenomenon is instead totally absent for workers with longer tenure periods. However, in the latter case, the variability of the wage gap sharply reduces for women with longer tenure periods and, unlike the group of low-educated, the wage gap sharply reduces at very low wage levels. Essentially, females with high levels of education benefit, in terms of gender differences in productive characteristics' rewards, from staying in the same firm for long periods.

\section{[Figures 3 and 4 around here]}

\section{Conclusions}

In this paper we evaluate the gender pay gap due to differences in characteristics' rewards by suggesting a distributional approach. In particular, the method assigns a probability of occurrence to any level of wage differential conditional to any level of a given factor or characteristic. The analysis shows that the component of the pay gap due to differences in productive characteristics' rewards between Italian men and women are not evenly distributed among workers with different educational endowments and other human capital characteristics. As expected, women achieving the highest educational levels experience lower pay gaps compared to their colleagues with lower education; furthermore, the variability of the wage gap along the range of estimated earnings is much higher for the loweducated than for the highly-educated. 
Our study also provides some interesting results when the interaction between education levels and other human capital characteristics is explicitly considered. In summary, the wage gap for low-educated females does not appear to be affected significantly by other human capital characteristics, such as general or firm-specific experience. This result suggests that the downward sloping distribution of the wage gap conditional on the wage level could be mainly explained by a positive selection of more experienced women earning middle and top wages; this confirms what de la Rica et al. (2008) found in the case of Spain. Conversely, for females with high educational levels, we may find substantial improvements in the wage gap range as workers' permanence in the firm increases, suggesting that gender differences in productivity estimated by employers at the beginning of employment may be partially unjustified. 


\section{References}

Addabbo, T. and Favaro D. (forthcoming) Gender wage differentials by education in Italy, Applied Economics.

Addis, E. and Waldmann, R. (1996) Struttura salariale e differenziale per sesso in Italia, Economia e lavoro, 30(1-2), 87-103.

Albrecht, J., Bjorklund, A. and Vroman, S. (2003) Is there a glass ceiling in Sweden?, Journal of Labor Economics, 21, 145-177.

Albrecht, J., Van Vuuren, A. and Vroman, S. (2004) Decomposing the gender wage gap in the Netherlands with sample selection adjustments, IZA DP 1400, Bonn.

Arulampalam, W., Booth, A.L., and Bryan, M.L. (2007) Is there a glass ceiling over Europe? Exploring the gender pay gap across the wages distribution, Industrial and Labor Relations Review, 60, 163-186.

Bayard, K., Hellerstein, J., Neumark, D. and Troske, K. (2003) New evidence on sex segregation and sex differences in wages from matched employee-employer data, Journal of Labor Economics, 21, 887-922.

Beblo, M., Beninger, D., Heinze, A. and Laisney, F. (2003) Methodological issues related to the analysis of gender gaps in employment, earnings and career progression, Final Report, European Commission, Employment and social affairs DG.

Blinder, A.S. (1973) Wage discrimination: reduced forms and structural estimates, The Journal of Human Resources, 8, 436-55.

Buchinsky M. (1998) Recent advances in quantile regression models: a practical guideline for empirical research, The Journal of Human Resources, 33, 88-126.

Chen, X., Linton, O. and Robinson, P.M. (2001) The estimation of conditional densities, The Suntory Centre discussion paper no. EM/01/415, LSE, London. 
De La Rica, S., Dolado, J.J. and Llorens, V. (2008) Ceiling and Floors: gender wage gaps by education in Spain, Journal of Population Economics, $21,751-776$.

Durlauf, S.N. and Quah, D.T. (1999) The new empirics of economic growth, in: Taylor J., Woodford M. (Eds.), Handbook of Macroeconomics, Vol. 1. North-Holland, Amsterdam, 235-308.

European Commission (2005), Employment in Europe 2005: Recent Trends and Prospects, Brusselles, European Communities.

Favaro, D. and Magrini S. (2008) Group versus individual discrimination among young workers: a distributional approach, Journal of SocioEconomics, 37, 1856-1879.

Flabbi, L. (1997) “Discriminazione di genere e rendimenti dell'istruzione: un'analisi su microdati", Rivista di Politica Economica, 12, 187-234.

Garcìa, J., Hernandez, P.J. and Lòpez-Nicolàs, A. (2001) How wide is the gap? An investigation of gender wage differences using quantile regression, Empirical Economics, 26, 149-167.

Gardeazàbal, J. and Ugidos, A. (2005) Gender wage discrimination at quantiles, Journal of Population Economics, 18, 165-179.

Fortin N.M. and Lemieux T. (1998) Rank regressions, wage distributions, and the gender wage gap, Journal of Human Resources, 33(3), 610-643.

ISTAT, 2005, Rapporto Annuale 2004, Roma, Istat.

Jenkins S. (1994) Earnings discrimination measurement: A distributional approach, Journal of Econometrics, 61, 81-102.

Koenker R. and Bassett G. (1982) Robust tests for heteroskedasticity on regression quantiles, Econometrica, 50, 43-61.

Machado, J.A.F. and Mata, J. (2005) Counterfactual decomposition of changes in wage distributions using quantile regression, Journal of Applied Econometrics, 20 (4), 445-465.

Oaxaca, R. (1973) Male-female wage differentials in urban labor markets, International Economic Review, 14, 693-709. 
Overman, H.G. and Ioannides, Y.M. (2001) Cross sectional evolution of the US city size distribution, Journal of Urban Economics, 49, 543-566.

Quah, D.T. (1996) Convergence empirics across economies with (some) capital mobility, Journal of Economic Growth, 1, 95-124.

Quah, D.T. (1997) Empirics for growth and distribution: stratification, polarization and convergence clubs, Journal of Economic Growth, 2, 27-59.

Rosenblatt, M. (1971) Curve estimates, Annals of Mathematical Statistics, 42, 1815-1842.

Rosti, L. (2006) La segregazione occupazionale in Italia, in Simonazzi A. (ed.), Questioni di Genere, Questioni di Politica, Roma, Carocci.

Silverman, B.W. (1986) Density Estimation for Statistics and Data Analysis, Chapman and Hall, London.

Stokey, N.L. and Lucas, R.E. Jr. (with Prescott E.C.) (1989) Recursive Methods in Economic Dynamics, Harvard University Press, Cambridge MA. Thurow, L.C. (1975) Generating Inequality, Basic Books, New York. 
Figures and Tables

Table 1

Incidence of the unexplained wage gap

\begin{tabular}{c|c|c|c}
\hline \multirow{2}{*}{$\begin{array}{c}\text { against / in favour of } \\
\text { females }\end{array}$} & $\begin{array}{c}\text { Educational level } \\
\text { relative to predicted } \\
\text { wage }\end{array}$ & High & Low \\
\hline \multirow{2}{*}{ against } & over 10\% & $15.06 \%$ & $29.70 \%$ \\
& between 5\% and 10\% & $31.14 \%$ & $18.02 \%$ \\
between 0 and 5\% & $39.60 \%$ & $19.67 \%$ \\
\hline
\end{tabular}


Figure 1

Probability density functions of the unexplained wage gap conditional on predicted earnings

\section{Low Education}
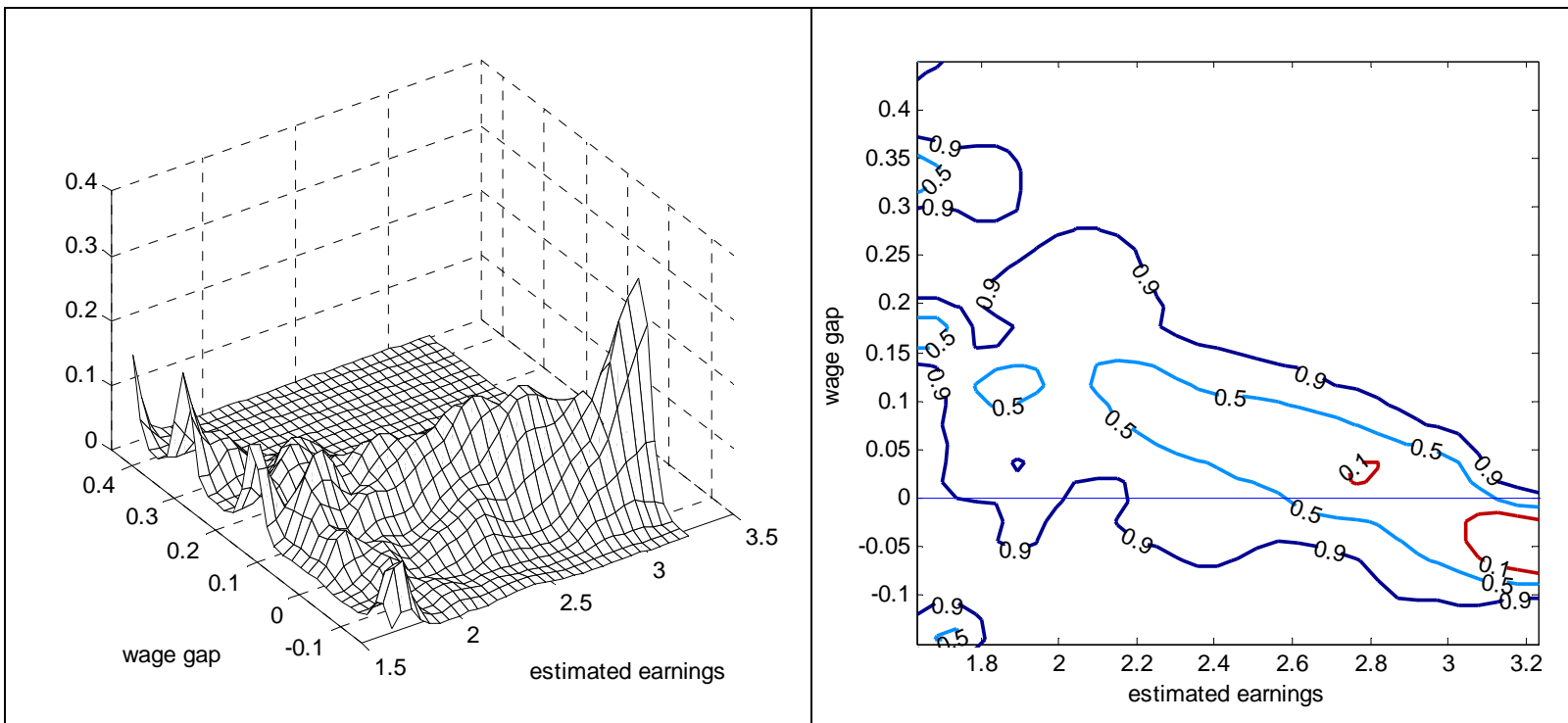

\section{High Education}

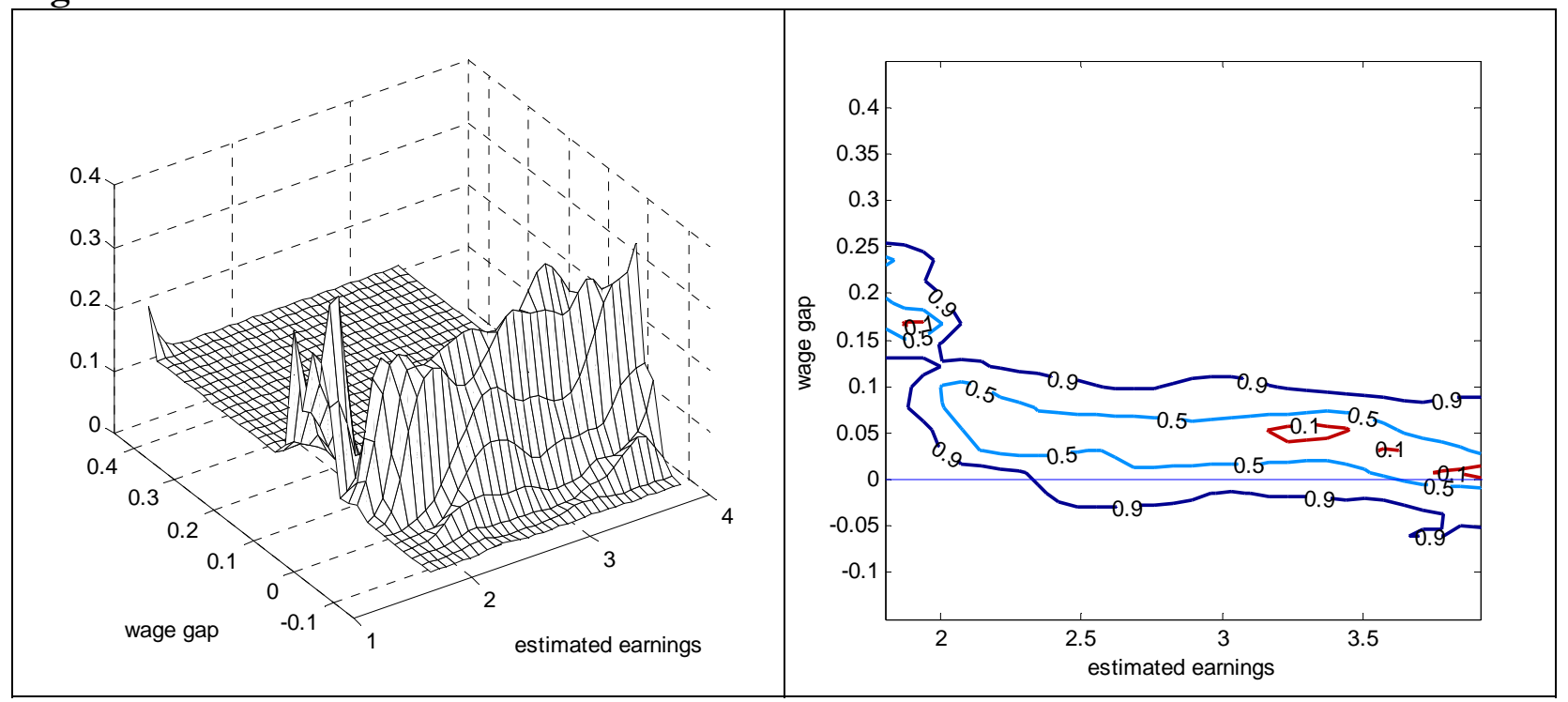

Notes: Predicted earnings are expressed in euros.

Wage gaps are expressed in relative terms with respect to predicted earnings.

Estimates use a Gaussian kernel with bandwidth chosen optimally (Silverman 1986). 
Figure 2

Probability density functions of the unexplained wage gap conditional on general experience

\section{Low Education}

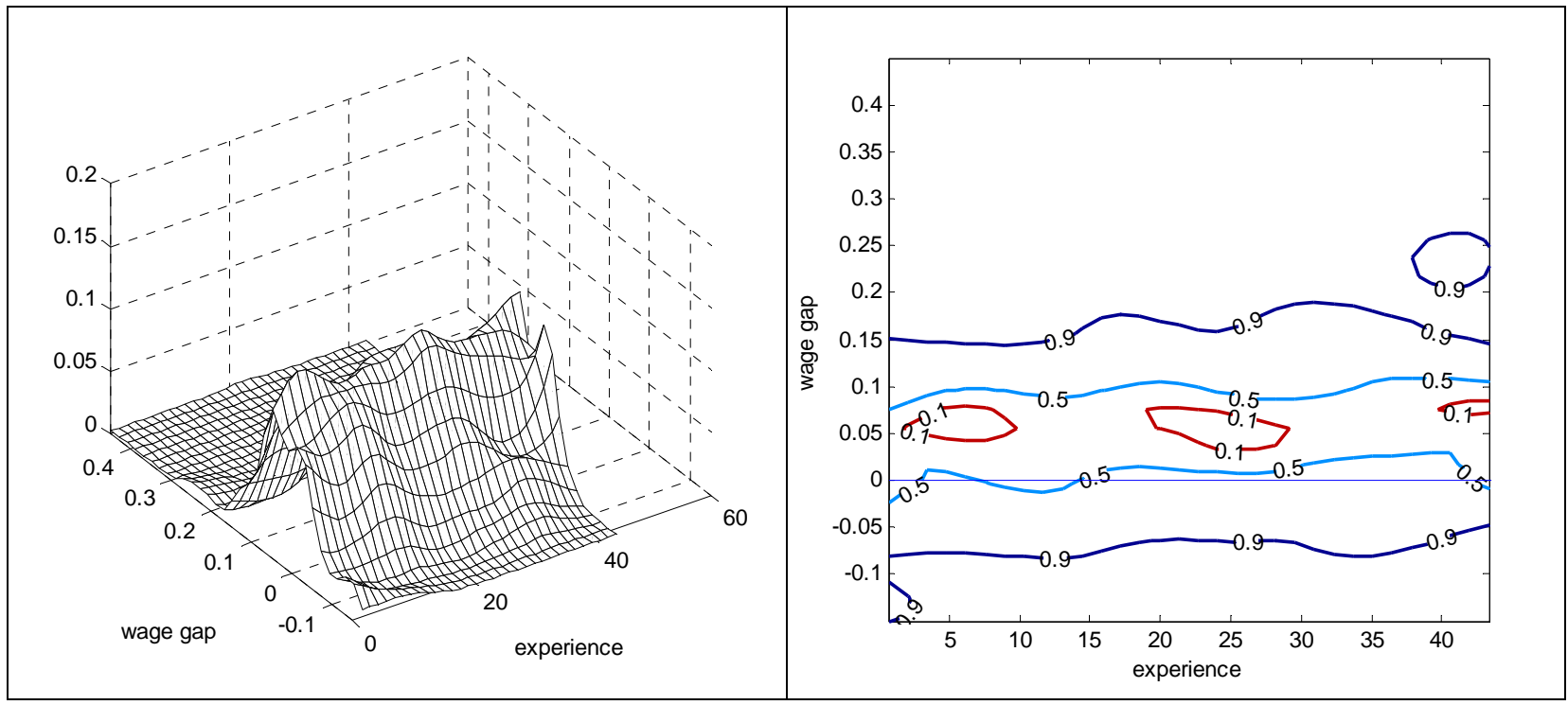

\section{High Education}

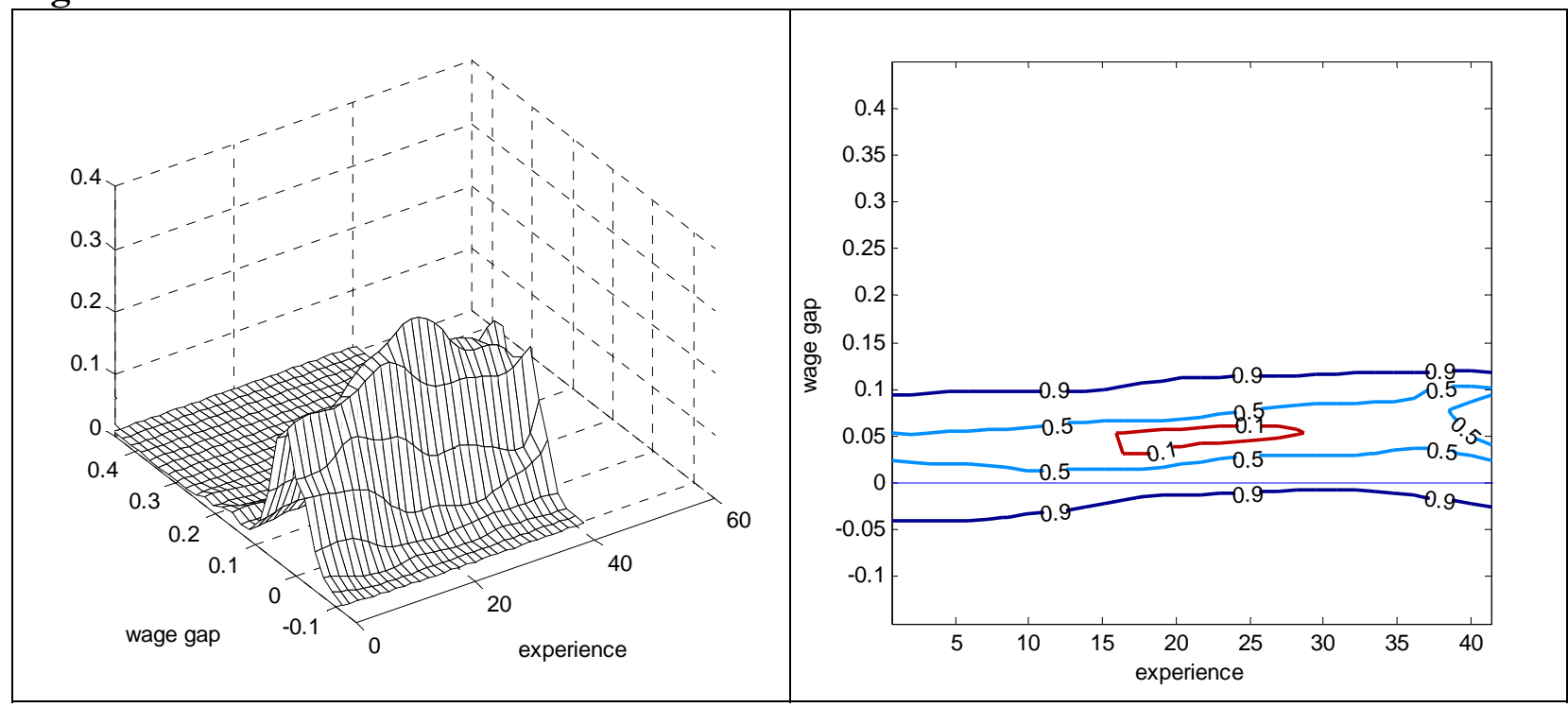

Notes: Predicted earnings are expressed in euros.

Wage gaps are expressed in relative terms with respect to predicted earnings.

Estimates use a Gaussian kernel with bandwidth chosen optimally (Silverman 1986). 
Figure 3

Probability density functions of the unexplained wage gap conditional on estimated earnings (for tenure of 10 years or less)

\section{Low Education}

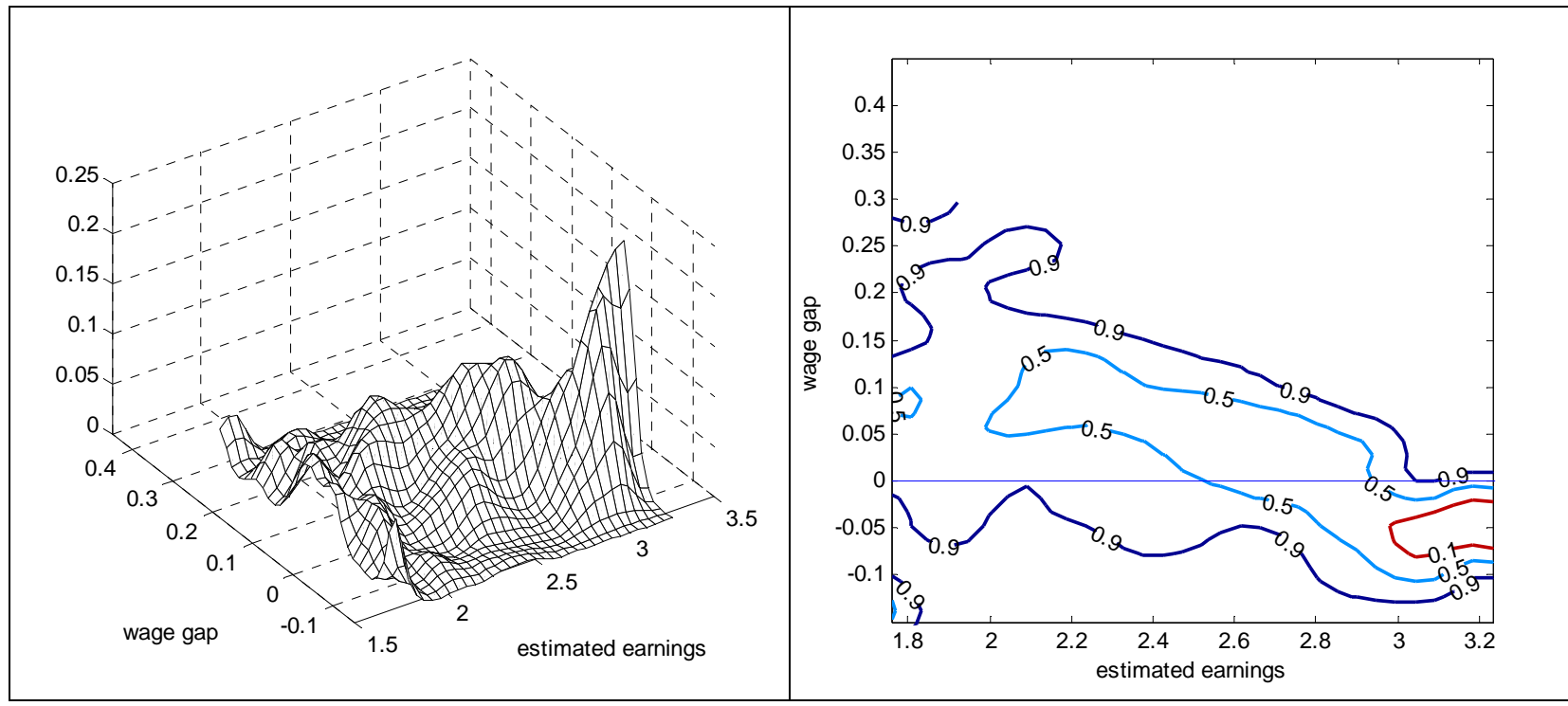

\section{High Education}

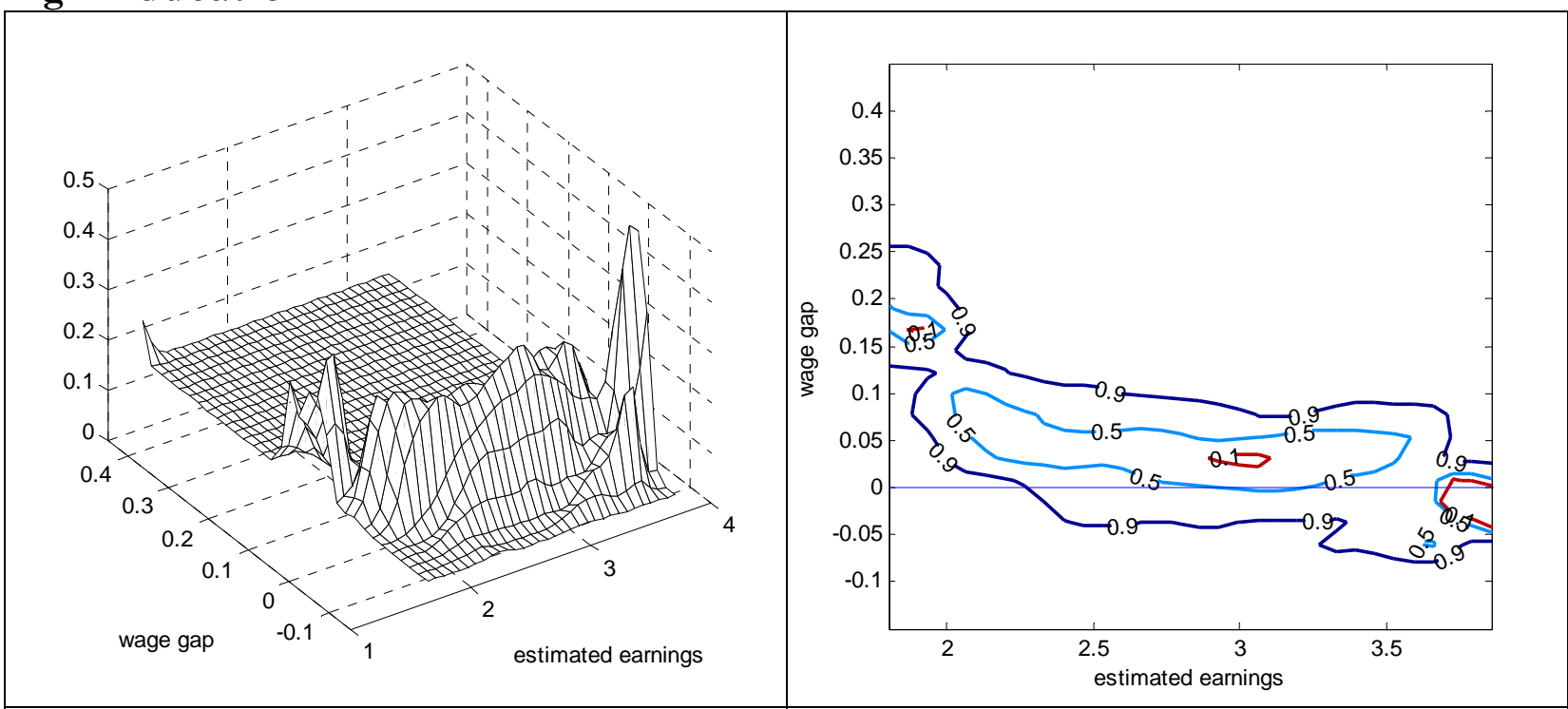

Notes: Predicted earnings are expressed in euros.

Wage gaps are expressed in relative terms with respect to predicted earnings.

Estimates use a Gaussian kernel with bandwidth chosen optimally (Silverman 1986). 
Figure 4

Probability density functions of the unexplained wage gap conditional on estimated earnings (for tenure of 11 years or more)

\section{Low Education}

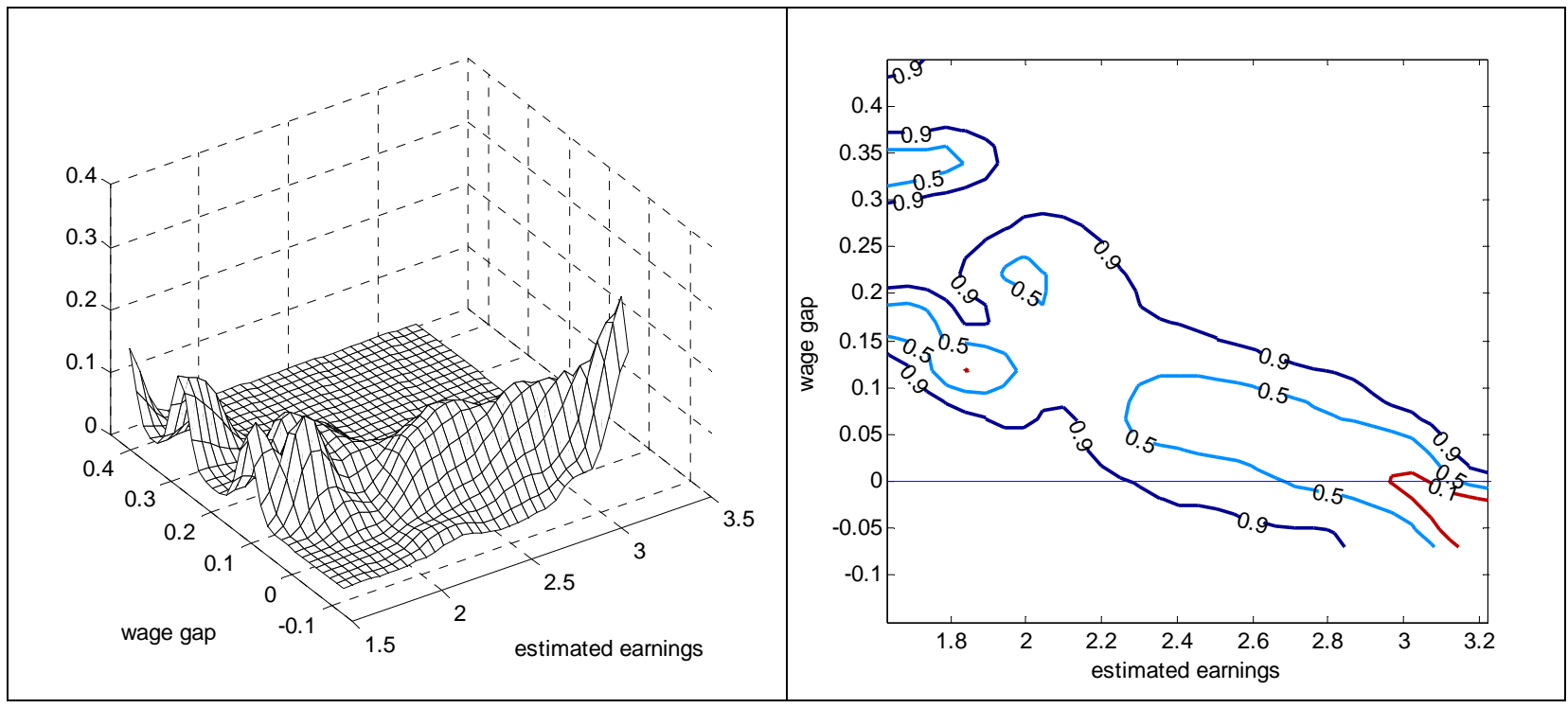

\section{High Education}

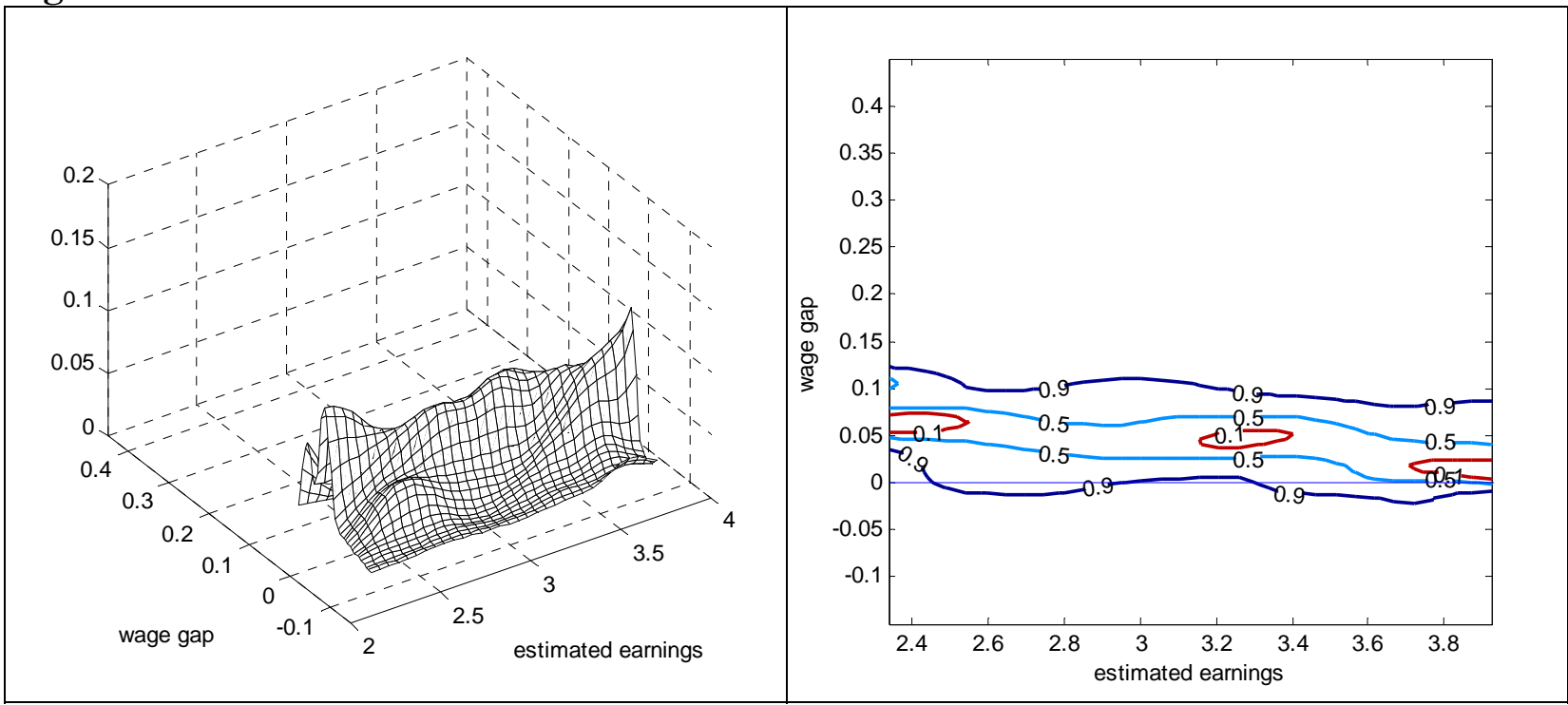

Notes: Predicted earnings are expressed in euros.

Wage gaps are expressed in relative terms with respect to predicted earnings.

Estimates use a Gaussian kernel with bandwidth chosen optimally (Silverman 1986). 


\section{Appendix}

\section{Table A1}

Type of occupation in current job. Distribution by education and gender (\%)

\begin{tabular}{lcccc}
\hline & \multicolumn{2}{c}{ Highly-educated } & \multicolumn{2}{c}{ Low-educated } \\
\hline & Women & Men & Women & Men \\
Legislators, senior officials and managers & 0.59 & 4.49 & 0.26 & 0.49 \\
Professionals & 26.97 & 11.87 & 0.51 & 0.10 \\
Technicians and associate professionals & 16.63 & 19.09 & 3.58 & 2.34 \\
Clerks & 38.39 & 27.83 & 15.86 & 7.50 \\
Service workers and shop and market sales workers & 10.04 & 8.26 & 18.67 & 10.33 \\
Skilled agricultural and fishery workers & 0.00 & 0.88 & 2.81 & 3.31 \\
Craft and related trades workers & 2.85 & 13.31 & 21.74 & 37.23 \\
Plant and machine operators and assemblers & 1.67 & 9.46 & 10.23 & 18.52 \\
Elementary occupations & 2.85 & 4.81 & 26.34 & 20.18 \\
\hline
\end{tabular}

Our elaborations on ECHP data (Italian sample). 
Table A2

Sample descriptive statistics

\begin{tabular}{|c|c|c|c|c|c|c|c|c|}
\hline \multirow[b]{4}{*}{ Log hourly wage } & \multicolumn{4}{|c|}{ Low-educated } & \multicolumn{4}{|c|}{ Highly-educated } \\
\hline & \multicolumn{2}{|c|}{ Women } & \multicolumn{2}{|c|}{ Men } & \multicolumn{2}{|c|}{ Women } & \multicolumn{2}{|c|}{ Men } \\
\hline & mean & S.D. & mean & S.D. & mean & S.D. & mean & S.D. \\
\hline & 2.45 & .33 & 2.59 & .32 & 2.79 & .42 & 2.87 & .43 \\
\hline Married/cohabiting & .63 & .48 & .71 & .45 & .64 & .48 & .66 & .47 \\
\hline Upper-stage of secondary education & - & - & - & - & .78 & .41 & .80 & .40 \\
\hline University education & - & - & - & - & .22 & .41 & .20 & .40 \\
\hline Experience & 18.09 & 10.96 & 20.01 & 11.80 & 14.45 & 9.92 & 15.63 & 10.40 \\
\hline Experience squared/10 & 44.71 & 43.47 & 53.91 & 51.58 & 30.72 & 34.25 & 35.27 & 36.96 \\
\hline Experience*Children & 3.74 & 7.45 & 7.26 & 10.40 & 5.14 & 8.00 & 6.22 & 9.29 \\
\hline Intermediate supervisory level & .08 & .27 & .10 & .30 & .13 & .33 & .21 & .41 \\
\hline High supervisory level & .03 & .17 & .05 & .21 & .07 & .26 & .17 & .37 \\
\hline Tenure $6-10$ years & .14 & .35 & .12 & .32 & .15 & .36 & .16 & .36 \\
\hline Tenure $11-15$ years & .12 & .33 & .10 & .30 & .11 & .32 & .11 & .31 \\
\hline Tenure more than 15 years & .31 & .46 & .33 & .47 & .34 & .47 & .36 & .48 \\
\hline Public Sector & .19 & .39 & .23 & .42 & .55 & .50 & .39 & .49 \\
\hline Agriculture & .06 & .24 & .07 & .25 & .00 & .05 & .02 & .15 \\
\hline Services & .59 & .49 & .44 & .50 & .87 & .33 & .65 & .48 \\
\hline Fixed-term or short-term contract & .11 & .32 & .07 & .26 & .07 & .26 & .05 & .22 \\
\hline Other contract & .09 & .29 & .08 & .27 & .03 & .16 & .02 & .02 \\
\hline Firm size: 5-19 employees & .36 & .48 & .32 & .47 & .27 & .44 & .24 & .24 \\
\hline Firm size: 20-49 employees & .16 & .37 & .13 & .34 & .17 & .38 & .19 & .19 \\
\hline Firm size 50-99 employees & .08 & .28 & .08 & .27 & .12 & .32 & .12 & .12 \\
\hline Firm size: 100-499 employees & .11 & .31 & .11 & .31 & .15 & .36 & .170 & .17 \\
\hline Firm size: $500+$ employees & .06 & .24 & .09 & .28 & .09 & .29 & .15 & .15 \\
\hline North-west & .08 & .28 & .07 & .25 & .12 & .32 & .10 & .10 \\
\hline North-east & .16 & .36 & .01 & .29 & .12 & .32 & .11 & .11 \\
\hline South and Islands & .20 & .40 & .35 & .48 & .25 & .43 & .28 & .28 \\
\hline
\end{tabular}

Source: Descriptive statistics on ECHP 2001 sample 
Table A3

Quantile regressions - Highly-educated workers

\begin{tabular}{|c|c|c|c|c|c|c|c|c|c|c|c|c|c|c|c|c|c|c|}
\hline & \multicolumn{9}{|c|}{ Women } & \multicolumn{9}{|c|}{ Men } \\
\hline & 10 th & 20 th & 30 th & 40 th & 50 th & 60 th & 70 th & 80 th & 90 th & 10 th & 20 th & 30 th & 40 th & $50 \mathrm{th}$ & 60 th & 70 th & 80 th & 90 th \\
\hline Married/cohabitating & $\begin{array}{c}.022 \\
(0.59)\end{array}$ & $\begin{array}{c}.035 \\
(1.00)\end{array}$ & $\begin{array}{l}.026 \\
(0.83)\end{array}$ & $\begin{array}{l}.022 \\
(0.74)\end{array}$ & $\begin{array}{c}0.26 \\
(0.89)\end{array}$ & $\begin{array}{c}.026 \\
(0.90)\end{array}$ & $\begin{array}{c}.017 \\
(0.63)\end{array}$ & $\begin{array}{c}.019 \\
(0.62)\end{array}$ & $\begin{array}{l}.051 \\
(1.45)\end{array}$ & $\begin{array}{l}-.047 \\
(-1.03)\end{array}$ & $\begin{array}{c}.024 \\
(0.70)\end{array}$ & $\begin{array}{l}.0416 \\
(1.41)\end{array}$ & $\begin{array}{c}.056 \\
(1.91)\end{array}$ & $\begin{array}{c}.055 \\
(1.72)\end{array}$ & $\begin{array}{l}.058 \\
(2.11)\end{array}$ & $\begin{array}{c}.052 \\
(1.68)\end{array}$ & $\begin{array}{c}.065 \\
(1.87)\end{array}$ & $\begin{array}{l}.071 \\
(1.46)\end{array}$ \\
\hline University education & $\begin{array}{l}.123 \\
(2.82)\end{array}$ & $\begin{array}{l}.144 \\
(3.20)\end{array}$ & $\begin{array}{l}.175 \\
(4.45)\end{array}$ & $\begin{array}{l}.186 \\
(5.28)\end{array}$ & $\begin{array}{l}.184 \\
(4.39)\end{array}$ & $\begin{array}{l}.228 \\
(5.50)\end{array}$ & $\begin{array}{l}.281 \\
(6.96)\end{array}$ & $\begin{array}{l}.322 \\
(6.97)\end{array}$ & $\begin{array}{l}.279 \\
(4.95)\end{array}$ & $\begin{array}{l}.128 \\
(3.25)\end{array}$ & $\begin{array}{l}.127 \\
(3.02)\end{array}$ & $\begin{array}{l}.192 \\
(4.75)\end{array}$ & $\begin{array}{l}.185 \\
(4.62)\end{array}$ & $\begin{array}{l}.224 \\
(4.64)\end{array}$ & $\begin{array}{l}.271 \\
(5.90)\end{array}$ & $\begin{array}{l}.265 \\
(5.55)\end{array}$ & $\begin{array}{l}.241 \\
(4.38)\end{array}$ & $\begin{array}{l}.271 \\
(4.24)\end{array}$ \\
\hline Experience & $\begin{array}{l}.013 \\
(1.65)\end{array}$ & $\begin{array}{l}.006 \\
(0.89)\end{array}$ & $\begin{array}{l}.008 \\
(1.42)\end{array}$ & $\begin{array}{l}.008 \\
(1.69)\end{array}$ & $\begin{array}{l}.007 \\
(1.66)\end{array}$ & $\begin{array}{l}.007 \\
(1.48)\end{array}$ & $\begin{array}{l}.003 \\
(0.56)\end{array}$ & $\begin{array}{l}.002 \\
(0.28)\end{array}$ & $\begin{array}{l}.005 \\
(0.56)\end{array}$ & $\begin{array}{l}.018 \\
(2.51)\end{array}$ & $\begin{array}{l}.014 \\
(2.37)\end{array}$ & $\begin{array}{l}.013 \\
(2.56)\end{array}$ & $\begin{array}{l}.013 \\
(2.60)\end{array}$ & $\begin{array}{l}.016 \\
(2.98)\end{array}$ & $\begin{array}{l}.012 \\
(2.33)\end{array}$ & $\begin{array}{l}.011 \\
(1.86)\end{array}$ & $\begin{array}{l}.013 \\
(1.80)\end{array}$ & $\begin{array}{l}.011 \\
(1.40)\end{array}$ \\
\hline Experience squared & $\begin{array}{l}-.000 \\
(-1.35)\end{array}$ & $\begin{array}{l}-.000 \\
(-0.33)\end{array}$ & $\begin{array}{c}-.000 \\
(-0.78)\end{array}$ & $\begin{array}{l}-.000 \\
(-1.23)\end{array}$ & $\begin{array}{l}-.000 \\
(-1.16)\end{array}$ & $\begin{array}{l}-.000 \\
(-0.59)\end{array}$ & $\begin{array}{c}.000 \\
(0.14)\end{array}$ & $\begin{array}{c}.000 \\
(0.37)\end{array}$ & $\begin{array}{l}-.000 \\
(-0.46)\end{array}$ & $\begin{array}{l}-.000 \\
(-1.56)\end{array}$ & $\begin{array}{l}-.000 \\
(-1.41)\end{array}$ & $\begin{array}{l}-.000 \\
(-1.23)\end{array}$ & $\begin{array}{l}-.000 \\
(-1.09)\end{array}$ & $\begin{array}{l}-.000 \\
(-1.81)\end{array}$ & $\begin{array}{l}-.000 \\
(-1.23)\end{array}$ & $\begin{array}{l}-.000 \\
(-1.03)\end{array}$ & $\begin{array}{l}-.000 \\
(-0.85)\end{array}$ & $\begin{array}{c}-.000 \\
(-0.50)\end{array}$ \\
\hline Experience*Children & $\begin{array}{l}-.0032 \\
(-2.03)\end{array}$ & $\begin{array}{c}-.001 \\
(-0.76)\end{array}$ & $\begin{array}{l}.000 \\
(0.13)\end{array}$ & $\begin{array}{l}.000 \\
(0.08)\end{array}$ & $\begin{array}{l}.001 \\
(0.66)\end{array}$ & $\begin{array}{l}.002 \\
(0.93)\end{array}$ & $\begin{array}{l}.002 \\
(1.12)\end{array}$ & $\begin{array}{l}.002 \\
(1.03)\end{array}$ & $\begin{array}{l}.001 \\
(0.69)\end{array}$ & $\begin{array}{l}.004 \\
(2.74)\end{array}$ & $\begin{array}{l}.002 \\
(1.89)\end{array}$ & $\begin{array}{l}.002 \\
(1.48)\end{array}$ & $\begin{array}{l}-.000 \\
(-0.05)\end{array}$ & $\begin{array}{l}.000 \\
(0.16)\end{array}$ & $\begin{array}{l}.000 \\
(0.11)\end{array}$ & $\begin{array}{l}-.000 \\
(-0.58)\end{array}$ & $\begin{array}{l}-.001 \\
(-.046)\end{array}$ & $\begin{array}{l}.000 \\
(0.20)\end{array}$ \\
\hline $\begin{array}{l}\text { Intermediate } \\
\text { supervisory level }\end{array}$ & $\begin{array}{c}.074 \\
(2.13)\end{array}$ & $\begin{array}{l}.034 \\
(1.13)\end{array}$ & $\begin{array}{l}.034 \\
(1.08)\end{array}$ & $\begin{array}{l}.047 \\
(1.52)\end{array}$ & $\begin{array}{l}.037 \\
(1.31)\end{array}$ & $\begin{array}{l}.022 \\
(0.73)\end{array}$ & $\begin{array}{l}.017 \\
(0.49)\end{array}$ & $\begin{array}{l}.010 \\
(0.23)\end{array}$ & $\begin{array}{l}.049 \\
(0.95)\end{array}$ & $\begin{array}{l}.082 \\
(2.04)\end{array}$ & $\begin{array}{l}.114 \\
(3.11)\end{array}$ & $\begin{array}{l}.104 \\
(3.18)\end{array}$ & $\begin{array}{l}.080 \\
(2.90)\end{array}$ & $\begin{array}{l}.078 \\
(3.11)\end{array}$ & $\begin{array}{l}.0999 \\
(3.71)\end{array}$ & $\begin{array}{l}.102 \\
(3.61)\end{array}$ & $\begin{array}{l}.090 \\
(3.12)\end{array}$ & $\begin{array}{l}.097 \\
(2.41)\end{array}$ \\
\hline High supervisory level & $\begin{array}{l}.133 \\
(2.52)\end{array}$ & $\begin{array}{l}.101 \\
(1.96)\end{array}$ & $\begin{array}{l}.068 \\
(1.29)\end{array}$ & $\begin{array}{l}.107 \\
(1.87)\end{array}$ & $\begin{array}{l}.144 \\
(2.53)\end{array}$ & $\begin{array}{l}.139 \\
(2.39)\end{array}$ & $\begin{array}{l}.146 \\
(2.33)\end{array}$ & $\begin{array}{l}.224 \\
(3.03)\end{array}$ & $\begin{array}{l}.291 \\
(3.34)\end{array}$ & $\begin{array}{l}.165 \\
(3.22)\end{array}$ & $\begin{array}{l}.171 \\
(4.00)\end{array}$ & $\begin{array}{l}.186 \\
(5.28)\end{array}$ & $\begin{array}{l}.170 \\
(4.94)\end{array}$ & $\begin{array}{l}.185 \\
(4.99)\end{array}$ & $\begin{array}{l}.219 \\
(5.70)\end{array}$ & $\begin{array}{l}.235 \\
(5.34)\end{array}$ & $\begin{array}{l}.284 \\
(4.30)\end{array}$ & $\begin{array}{l}.361 \\
(4.14)\end{array}$ \\
\hline Tenure $6-10$ years & $\begin{array}{l}.079 \\
(1.61)\end{array}$ & $\begin{array}{l}.062 \\
(1.25)\end{array}$ & $\begin{array}{l}.045 \\
(1.06)\end{array}$ & $\begin{array}{l}.059 \\
(1.66)\end{array}$ & $\begin{array}{l}.051 \\
(1.45)\end{array}$ & $\begin{array}{l}.055 \\
(1.53)\end{array}$ & $\begin{array}{l}.056 \\
(1.33)\end{array}$ & $\begin{array}{l}.060 \\
(1.23)\end{array}$ & $\begin{array}{l}.049 \\
(0.78)\end{array}$ & $\begin{array}{l}.108 \\
(2.18)\end{array}$ & $\begin{array}{l}.098 \\
(2.37)\end{array}$ & $\begin{array}{l}.076 \\
(2.04)\end{array}$ & $\begin{array}{l}.072 \\
(2.08)\end{array}$ & $\begin{array}{l}.031 \\
(0.99)\end{array}$ & $\begin{array}{l}.047 \\
(1.38)\end{array}$ & $\begin{array}{l}.022 \\
(0.64)\end{array}$ & $\begin{array}{c}.018 \\
(0.42)\end{array}$ & $\begin{array}{c}.042 \\
(0.73)\end{array}$ \\
\hline Tenure $11-15$ years & $\begin{array}{l}.203 \\
(3.66)\end{array}$ & $\begin{array}{l}.131 \\
(2.72)\end{array}$ & $\begin{array}{l}.049 \\
(1.09)\end{array}$ & $\begin{array}{l}.063 \\
(1.48)\end{array}$ & $\begin{array}{l}.069 \\
(1.68)\end{array}$ & $\begin{array}{l}.065 \\
(1.61)\end{array}$ & $\begin{array}{l}.070 \\
(1.84)\end{array}$ & $\begin{array}{l}.057 \\
(1.37)\end{array}$ & $\begin{array}{l}.024 \\
(0.38)\end{array}$ & $\begin{array}{l}.155 \\
(2.31)\end{array}$ & $\begin{array}{l}.108 \\
(2.10)\end{array}$ & $\begin{array}{l}.086 \\
(1.86)\end{array}$ & $\begin{array}{l}.093 \\
(2.19)\end{array}$ & $\begin{array}{l}.038 \\
(0.91)\end{array}$ & $\begin{array}{l}.065 \\
(1.69)\end{array}$ & $\begin{array}{l}.071 \\
(1.58)\end{array}$ & $\begin{array}{l}.053 \\
(0.93)\end{array}$ & $\begin{array}{l}.076 \\
(1.20)\end{array}$ \\
\hline $\begin{array}{l}\text { Tenure more than } 15 \\
\text { years }\end{array}$ & $\begin{array}{l}.171 \\
(2.96)\end{array}$ & $\begin{array}{l}.126 \\
(2.25)\end{array}$ & $\begin{array}{l}.073 \\
(1.35)\end{array}$ & $\begin{array}{c}.064 \\
(1.46)\end{array}$ & $\begin{array}{l}.084 \\
(1.94)\end{array}$ & $\begin{array}{l}.099 \\
(2.16)\end{array}$ & $\begin{array}{l}.104 \\
(2.38)\end{array}$ & $\begin{array}{l}.133 \\
(2.62)\end{array}$ & $\begin{array}{l}.154 \\
(2.34)\end{array}$ & $\begin{array}{l}.160 \\
(3.01)\end{array}$ & $\begin{array}{l}.138 \\
(3.41)\end{array}$ & $\begin{array}{l}.109 \\
(2.46)\end{array}$ & $\begin{array}{l}.100 \\
(2.52)\end{array}$ & $\begin{array}{l}.076 \\
(2.05)\end{array}$ & $\begin{array}{l}.101 \\
(2.82)\end{array}$ & $\begin{array}{l}.089 \\
(2.16)\end{array}$ & $\begin{array}{c}.053 \\
(1.08)\end{array}$ & $\begin{array}{l}.112 \\
(1.92)\end{array}$ \\
\hline Public sector & $\begin{array}{l}.192 \\
(4.45)\end{array}$ & $\begin{array}{l}.163 \\
(4.46)\end{array}$ & $\begin{array}{l}.129 \\
(3.85)\end{array}$ & $\begin{array}{l}.133 \\
(4.43)\end{array}$ & $\begin{array}{l}.118 \\
(3.62)\end{array}$ & $\begin{array}{l}.092 \\
(2.78)\end{array}$ & $\begin{array}{l}.062 \\
(1.86)\end{array}$ & $\begin{array}{l}.032 \\
(0.82)\end{array}$ & $\begin{array}{l}-.028 \\
(-0.59)\end{array}$ & $\begin{array}{l}.060 \\
(1.61)\end{array}$ & $\begin{array}{l}.070 \\
(2.03)\end{array}$ & $\begin{array}{l}.082 \\
(2.83)\end{array}$ & $\begin{array}{l}.051 \\
(1.87)\end{array}$ & $\begin{array}{l}.071 \\
(2.55)\end{array}$ & $\begin{array}{l}.046 \\
(1.63)\end{array}$ & $\begin{array}{l}.0399 \\
(1.36)\end{array}$ & $\begin{array}{l}.036 \\
(1.02)\end{array}$ & $\begin{array}{l}.021 \\
(0.50)\end{array}$ \\
\hline Agriculture & $\begin{array}{l}-1.057 \\
(-1.73)\end{array}$ & $\begin{array}{l}-.1 .159 \\
(-1.93)\end{array}$ & $\begin{array}{l}-1.128 \\
(-1.91)\end{array}$ & $\begin{array}{l}-1.152 \\
(-2.01)\end{array}$ & $\begin{array}{l}-.238 \\
(-0.45)\end{array}$ & $\begin{array}{l}-.252 \\
(-0.51)\end{array}$ & $\begin{array}{l}-.381 \\
(-0.86)\end{array}$ & $\begin{array}{l}-.498 \\
(-1.18)\end{array}$ & $\begin{array}{l}-.563 \\
(-1.38)\end{array}$ & $\begin{array}{l}-.200 \\
(-1.65)\end{array}$ & $\begin{array}{l}-.236 \\
(-2.23)\end{array}$ & $\begin{array}{l}-.264 \\
(-2.56)\end{array}$ & $\begin{array}{l}-.268 \\
(-2.77)\end{array}$ & $\begin{array}{l}-.237 \\
(-2.25)\end{array}$ & $\begin{array}{l}-.208 \\
(-2.04)\end{array}$ & $\begin{array}{l}-.202 \\
(-1.96)\end{array}$ & $\begin{array}{l}-.100 \\
(-0.81)\end{array}$ & $\begin{array}{l}-.126 \\
(-1.04)\end{array}$ \\
\hline Services & $\begin{array}{l}-.018 \\
(-0.35)\end{array}$ & $\begin{array}{c}.011 \\
(0.20)\end{array}$ & $\begin{array}{l}-.005 \\
(-0.09)\end{array}$ & $\begin{array}{l}.003 \\
(0.08)\end{array}$ & $\begin{array}{l}-.014 \\
(-0.37)\end{array}$ & $\begin{array}{c}.013 \\
(0.31)\end{array}$ & $\begin{array}{c}.030 \\
(0.69)\end{array}$ & $\begin{array}{c}.022 \\
(0.50)\end{array}$ & $\begin{array}{l}.075 \\
(1.57)\end{array}$ & $\begin{array}{c}-.034 \\
(-0.95)\end{array}$ & $\begin{array}{l}.001 \\
(0.03)\end{array}$ & $\begin{array}{c}-.023 \\
(-0.62)\end{array}$ & $\begin{array}{l}-.012 \\
(-0.44)\end{array}$ & $\begin{array}{l}-.002 \\
(-0.09)\end{array}$ & $\begin{array}{c}.017 \\
(0.72)\end{array}$ & $\begin{array}{c}.016 \\
(0.52)\end{array}$ & $\begin{array}{l}.050 \\
(1.41)\end{array}$ & $\begin{array}{c}.063 \\
(1.19)\end{array}$ \\
\hline $\begin{array}{l}\text { Fixed-short-term } \\
\text { contract }\end{array}$ & $\begin{array}{l}.005 \\
(0.07)\end{array}$ & $\begin{array}{l}-.022 \\
(-0.31)\end{array}$ & $\begin{array}{l}-.066 \\
(-1.17)\end{array}$ & $\begin{array}{l}-.072 \\
(-1.40)\end{array}$ & $\begin{array}{c}-.041 \\
(-0.78)\end{array}$ & $\begin{array}{c}-.011 \\
(-0.22)\end{array}$ & $\begin{array}{l}-.002 \\
(-0.03)\end{array}$ & $\begin{array}{l}-.015 \\
(-0.29)\end{array}$ & $\begin{array}{l}.006 \\
(0.07)\end{array}$ & $\begin{array}{l}-.047 \\
(-0.64)\end{array}$ & $\begin{array}{l}-.048 \\
(-0.83)\end{array}$ & $\begin{array}{l}-.039 \\
(-0.73)\end{array}$ & $\begin{array}{l}-.069 \\
(-1.43)\end{array}$ & $\begin{array}{c}-.096 \\
(-1.60)\end{array}$ & $\begin{array}{c}-.095 \\
(-1.30)\end{array}$ & $\begin{array}{c}-.037 \\
(-0.48)\end{array}$ & $\begin{array}{c}-.004 \\
(-0.04)\end{array}$ & $\begin{array}{l}.042 \\
(0.58)\end{array}$ \\
\hline Other type of contract & $\begin{array}{l}-.133 \\
(-0.88)\end{array}$ & $\begin{array}{l}-.101 \\
(-0.94)\end{array}$ & $\begin{array}{l}-.167 \\
(-1.27)\end{array}$ & $\begin{array}{l}-.076 \\
(-0.59)\end{array}$ & $\begin{array}{c}-.062 \\
(-0.66)\end{array}$ & $\begin{array}{c}-.066 \\
(-0.84)\end{array}$ & $\begin{array}{c}-.167 \\
(-2.46)\end{array}$ & $\begin{array}{c}-.187 \\
(-2.55)\end{array}$ & $\begin{array}{c}-.162 \\
(-1.72)\end{array}$ & $\begin{array}{c}.072 \\
(0.92)\end{array}$ & $\begin{array}{l}.066 \\
(0.67)\end{array}$ & $\begin{array}{c}.044 \\
(0.37)\end{array}$ & $\begin{array}{c}.068 \\
(0.48)\end{array}$ & $\begin{array}{c}.097 \\
(0.60)\end{array}$ & $\begin{array}{l}.225 \\
(1.51)\end{array}$ & $\begin{array}{l}.199 \\
(1.05)\end{array}$ & $\begin{array}{l}.223 \\
(1.05)\end{array}$ & $\begin{array}{l}.556 \\
(2.44)\end{array}$ \\
\hline Constant & $\begin{array}{c}1.874 \\
(10.94)\end{array}$ & $\begin{array}{c}1.958 \\
(13.24)\end{array}$ & $\begin{array}{c}2.141 \\
(16.39)\end{array}$ & $\begin{array}{c}2.174 \\
(17.12)\end{array}$ & $\begin{array}{l}2.236 \\
(26.03)\end{array}$ & $\begin{array}{l}2.266 \\
(25.02)\end{array}$ & $\begin{array}{l}.2 .318 \\
(20.93)\end{array}$ & $\begin{array}{c}2.370 \\
(20.35)\end{array}$ & $\begin{array}{c}2.340 \\
(16.49)\end{array}$ & $\begin{array}{c}2.122 \\
(12.08)\end{array}$ & $\begin{array}{c}2.199 \\
(24.83)\end{array}$ & $\begin{array}{c}2.285 \\
(33.44)\end{array}$ & $\begin{array}{c}2.318 \\
(36.18)\end{array}$ & $\begin{array}{l}2.322 \\
(34.65)\end{array}$ & $\begin{array}{c}2.359 \\
(35.91)\end{array}$ & $\begin{array}{c}2.363 \\
(27.61)\end{array}$ & $\begin{array}{c}0.540 \\
(24.23)\end{array}$ & $\begin{array}{c}2.517 \\
(29.39)\end{array}$ \\
\hline $\mathrm{R}^{2}$ & .378 & .335 & .319 & .322 & .328 & .349 & .377 & .410 & .437 & .313 & .304 & .309 & .318 & .329 & .353 & .380 & .412 & .453 \\
\hline Observations & & & & & 831 & & & & & & & & & 1044 & & & & \\
\hline
\end{tabular}

t-values in brackets.

The specifications include dummies by firm size, macro-region and occupational category. Complete tables available upon request. 
Table A4

Quantile regressions - Low-educated workers

\begin{tabular}{|c|c|c|c|c|c|c|c|c|c|c|c|c|c|c|c|c|c|c|}
\hline & \multicolumn{9}{|c|}{ Women } & \multicolumn{9}{|c|}{ Men } \\
\hline & 10 th & 20 th & 30 th & 40 th & 50 th & 60 th & $70^{\mathrm{th}}$ & 80 th & 90 th & 10 th & 20 th & 30 th & 40 th & 50 th & 60 th & 70 th & 80 th & 90 th \\
\hline Married/cohabitating & $\begin{array}{c}.053 \\
(1.08)\end{array}$ & $\begin{array}{c}.018 \\
(0.37)\end{array}$ & $\begin{array}{l}.030 \\
(0.62)\end{array}$ & $\begin{array}{l}-.016 \\
(-0.35)\end{array}$ & $\begin{array}{l}-.032 \\
(-0.68)\end{array}$ & $\begin{array}{c}-.038 \\
(-0.82)\end{array}$ & $\begin{array}{l}-.047 \\
(-0.93)\end{array}$ & $\begin{array}{c}-.013 \\
(-0.27)\end{array}$ & $\begin{array}{c}-.052 \\
(-1.00)\end{array}$ & $\begin{array}{l}.045 \\
(1.04)\end{array}$ & $\begin{array}{l}.068 \\
(1.85)\end{array}$ & $\begin{array}{l}.079 \\
(2.49)\end{array}$ & $\begin{array}{c}.080 \\
(2.80)\end{array}$ & $\begin{array}{c}.069 \\
(2.38)\end{array}$ & $\begin{array}{c}.058 \\
(2.00)\end{array}$ & $\begin{array}{c}.065 \\
(2.57)\end{array}$ & $\begin{array}{c}.072 \\
(2.70)\end{array}$ & $\begin{array}{c}.080 \\
(2.13)\end{array}$ \\
\hline Experience & $\begin{array}{c}.010 \\
(1.01)\end{array}$ & $\begin{array}{l}.016 \\
(1.82)\end{array}$ & $\begin{array}{l}.014 \\
(1.73)\end{array}$ & $\begin{array}{l}.009 \\
(1.02)\end{array}$ & $\begin{array}{l}.010 \\
(1.05)\end{array}$ & $\begin{array}{c}.009 \\
(0.86)\end{array}$ & $\begin{array}{c}.005 \\
(0.45)\end{array}$ & $\begin{array}{c}.002 \\
(0.15)\end{array}$ & $\begin{array}{c}.005 \\
(0.44)\end{array}$ & $\begin{array}{c}.025 \\
(2.96)\end{array}$ & $\begin{array}{c}.017 \\
(2.54)\end{array}$ & $\begin{array}{c}.010 \\
(1.80)\end{array}$ & $\begin{array}{c}.006 \\
(1.28)\end{array}$ & $\begin{array}{c}.006 \\
(1.32)\end{array}$ & $\begin{array}{c}.004 \\
(0.91)\end{array}$ & $\begin{array}{c}.001 \\
(0.17)\end{array}$ & $\begin{array}{c}-.002 \\
(-0.42)\end{array}$ & $\begin{array}{c}-.006 \\
(-0.94)\end{array}$ \\
\hline Experience squared & $\begin{array}{c}-.000 \\
(-1.04)\end{array}$ & $\begin{array}{c}-.000 \\
(-1.67)\end{array}$ & $\begin{array}{c}-.000 \\
(-1.53)\end{array}$ & $\begin{array}{c}-.000 \\
(-0.82)\end{array}$ & $\begin{array}{l}-.000 \\
(-0.96)\end{array}$ & $\begin{array}{c}-.000 \\
(-0.84)\end{array}$ & $\begin{array}{c}-.000 \\
(-0.47)\end{array}$ & $\begin{array}{c}-.000 \\
(-0.26)\end{array}$ & $\begin{array}{c}-.000 \\
(-0.39)\end{array}$ & $\begin{array}{c}-.000 \\
(-2.50)\end{array}$ & $\begin{array}{c}-.000 \\
(-2.45)\end{array}$ & $\begin{array}{c}-.000 \\
(-1.67)\end{array}$ & $\begin{array}{c}-.000 \\
(-1.05)\end{array}$ & $\begin{array}{c}-.000 \\
(-0.92)\end{array}$ & $\begin{array}{c}-.000 \\
(-0.19)\end{array}$ & $\begin{array}{c}.000 \\
(0.24)\end{array}$ & $\begin{array}{c}.000 \\
(0.73)\end{array}$ & $\begin{array}{c}.000 \\
(1.26)\end{array}$ \\
\hline Experience ${ }^{*}$ Children & $\begin{array}{l}.001 \\
(0.29)\end{array}$ & $\begin{array}{l}-.002 \\
(-0.78)\end{array}$ & $\begin{array}{l}-.002 \\
(-0.83)\end{array}$ & $\begin{array}{l}.000 \\
(0.11)\end{array}$ & $\begin{array}{l}-.001 \\
(-0.36)\end{array}$ & $\begin{array}{l}-.001 \\
(-0.51)\end{array}$ & $\begin{array}{l}.001 \\
(0.45)\end{array}$ & $\begin{array}{l}-.001 \\
(-0.26)\end{array}$ & $\begin{array}{l}-.004 \\
(-1.18)\end{array}$ & $\begin{array}{l}.005 \\
(0.39)\end{array}$ & $\begin{array}{l}-.000 \\
(-0.04)\end{array}$ & $\begin{array}{l}-.000 \\
(-0.03)\end{array}$ & $\begin{array}{l}.001 \\
(1.04)\end{array}$ & $\begin{array}{l}.001 \\
(1.45)\end{array}$ & $\begin{array}{l}.001 \\
(1.43)\end{array}$ & $\begin{array}{l}.001 \\
(1.26)\end{array}$ & $\begin{array}{c}.002 \\
(2.03)\end{array}$ & $\begin{array}{c}.004 \\
(2.49)\end{array}$ \\
\hline ediate & $\begin{array}{l}-.005 \\
(-0.06)\end{array}$ & $\begin{array}{l}.047 \\
(0.65)\end{array}$ & $\begin{array}{l}.012 \\
(0.16)\end{array}$ & $\begin{array}{c}.029 \\
(0.39)\end{array}$ & $\begin{array}{c}.062 \\
(0.80)\end{array}$ & $\begin{array}{l}.032 \\
(0.39)\end{array}$ & $\begin{array}{l}.014 \\
(0.18)\end{array}$ & $\begin{array}{l}.026 \\
(0.33)\end{array}$ & $\begin{array}{l}.129 \\
(1.33)\end{array}$ & $\begin{array}{c}.063 \\
(1.05)\end{array}$ & $\begin{array}{l}.075 \\
(1.36)\end{array}$ & $\begin{array}{l}.134 \\
(3.14)\end{array}$ & $\begin{array}{l}.096 \\
(3.02)\end{array}$ & $\begin{array}{l}.097 \\
(3.67)\end{array}$ & $\begin{array}{c}.073 \\
(2.62)\end{array}$ & $\begin{array}{l}.055 \\
(1.87)\end{array}$ & $\begin{array}{l}.046 \\
(1.33)\end{array}$ & $\begin{array}{c}0.38 \\
(0.76)\end{array}$ \\
\hline $\begin{array}{l}\text { High supervisory } \\
\text { level }\end{array}$ & $\begin{array}{c}-.023 \\
(-0.15)\end{array}$ & $\begin{array}{l}.030 \\
(0.20)\end{array}$ & $\begin{array}{l}.103 \\
(0.67)\end{array}$ & $\begin{array}{l}.105 \\
(0.72)\end{array}$ & $\begin{array}{l}.078 \\
(0.59)\end{array}$ & $\begin{array}{l}.071 \\
(0.49)\end{array}$ & $\begin{array}{l}.146 \\
(0.99)\end{array}$ & $\begin{array}{l}.208 \\
(1.50)\end{array}$ & $\begin{array}{l}.236 \\
(1.93)\end{array}$ & $\begin{array}{l}-.020 \\
(-0.24)\end{array}$ & $\begin{array}{l}.044 \\
(0.58)\end{array}$ & $\begin{array}{l}.057 \\
(0.76)\end{array}$ & $\begin{array}{l}.037 \\
(0.46)\end{array}$ & $\begin{array}{l}.124 \\
(1.63)\end{array}$ & $\begin{array}{l}.128 \\
(1.94)\end{array}$ & $\begin{array}{l}.139 \\
(2.27)\end{array}$ & $\begin{array}{l}.141 \\
(2.25)\end{array}$ & $\begin{array}{l}.131 \\
(1.85)\end{array}$ \\
\hline Tenure $6-10$ years & $\begin{array}{l}.085 \\
(1.00)\end{array}$ & $\begin{array}{c}.038 \\
(0.60)\end{array}$ & $\begin{array}{c}.038 \\
(0.60)\end{array}$ & $\begin{array}{l}.000 \\
(0.01)\end{array}$ & $\begin{array}{c}.002 \\
(0.05)\end{array}$ & $\begin{array}{l}.031 \\
(0.50)\end{array}$ & $\begin{array}{l}.035 \\
(0.52)\end{array}$ & $\begin{array}{l}.028 \\
(0.44)\end{array}$ & $\begin{array}{c}-.084 \\
(-1.17)\end{array}$ & $\begin{array}{c}-.004 \\
(-0.08)\end{array}$ & $\begin{array}{c}.032 \\
(0.68)\end{array}$ & $\begin{array}{l}.011 \\
(0.30)\end{array}$ & $\begin{array}{l}.013 \\
(0.41)\end{array}$ & $\begin{array}{c}.033 \\
(1.00)\end{array}$ & $\begin{array}{c}.026 \\
(0.70)\end{array}$ & $\begin{array}{c}.018 \\
(0.48)\end{array}$ & $\begin{array}{c}.005 \\
(0.12)\end{array}$ & $\begin{array}{c}.032 \\
(0.63)\end{array}$ \\
\hline Tenure $11-15$ years & $\begin{array}{l}-.009 \\
(-0.10)\end{array}$ & $\begin{array}{l}.010 \\
(0.16)\end{array}$ & $\begin{array}{l}-.014 \\
(-0.22)\end{array}$ & $\begin{array}{l}-.005 \\
(-0.09)\end{array}$ & $\begin{array}{l}.041 \\
(0.65)\end{array}$ & $\begin{array}{l}.044 \\
(0.65)\end{array}$ & $\begin{array}{l}.003 \\
(0.04)\end{array}$ & $\begin{array}{l}.007 \\
(0.10)\end{array}$ & $\begin{array}{l}-.041 \\
(-0.48)\end{array}$ & $\begin{array}{l}.004 \\
(0.07)\end{array}$ & $\begin{array}{l}-.054 \\
(-1.07)\end{array}$ & $\begin{array}{l}-.009 \\
(-0.18)\end{array}$ & $\begin{array}{l}.013 \\
(0.31)\end{array}$ & $\begin{array}{l}.018 \\
(0.56)\end{array}$ & $\begin{array}{l}.012 \\
(0.34)\end{array}$ & $\begin{array}{l}-.014 \\
(-0.45)\end{array}$ & $\begin{array}{l}-.016 \\
(-0.41)\end{array}$ & $\begin{array}{l}.037 \\
(0.55)\end{array}$ \\
\hline $\begin{array}{l}\text { Tenure more than } 15 \\
\text { years }\end{array}$ & & $\begin{array}{c}-.035 \\
(-0.50)\end{array}$ & $\begin{array}{l}.030 \\
(0.44)\end{array}$ & $\begin{array}{c}.057 \\
(0.93)\end{array}$ & $\begin{array}{c}.064 \\
(1.20)\end{array}$ & $\begin{array}{c}.080 \\
(1.26)\end{array}$ & $\begin{array}{l}.101 \\
(1.37)\end{array}$ & $\begin{array}{c}.154 \\
(2.07)\end{array}$ & $\begin{array}{c}.082 \\
(1.00)\end{array}$ & $\begin{array}{l}.061 \\
(1.26)\end{array}$ & $\begin{array}{l}.064 \\
(1.84)\end{array}$ & $\begin{array}{c}.075 \\
(2.15)\end{array}$ & $\begin{array}{c}.084 \\
(2.65)\end{array}$ & $\begin{array}{c}.093 \\
(3.27)\end{array}$ & $\begin{array}{c}.071 \\
(2.13)\end{array}$ & $\begin{array}{l}.053 \\
(1.48)\end{array}$ & $\begin{array}{c}.075 \\
(2.23)\end{array}$ & $\begin{array}{c}.046 \\
(0.98)\end{array}$ \\
\hline lic sector & $\begin{array}{l}.141 \\
(2.28)\end{array}$ & $\begin{array}{c}.089 \\
(1.44)\end{array}$ & $\begin{array}{l}.091 \\
(1.54)\end{array}$ & $\begin{array}{c}.042 \\
(0.70)\end{array}$ & $\begin{array}{c}.073 \\
(1.34)\end{array}$ & $\begin{array}{c}.079 \\
(1.28)\end{array}$ & $\begin{array}{l}-.024 \\
(-0.38)\end{array}$ & $\begin{array}{c}-.072 \\
(-1.04)\end{array}$ & $\begin{array}{c}-.099 \\
(-1.26)\end{array}$ & $\begin{array}{l}.120 \\
(1.93)\end{array}$ & $\begin{array}{l}.124 \\
(2.83)\end{array}$ & $\begin{array}{c}.090 \\
(2.43)\end{array}$ & $\begin{array}{l}.045 \\
(1.32)\end{array}$ & $\begin{array}{c}.042 \\
(1.34)\end{array}$ & $\begin{array}{c}.053 \\
(1.53)\end{array}$ & $\begin{array}{c}.074 \\
(1.95)\end{array}$ & $\begin{array}{c}.054 \\
(1.41)\end{array}$ & $\begin{array}{c}.028 \\
(0.56)\end{array}$ \\
\hline & $\begin{array}{l}-.171 \\
(-0.74)\end{array}$ & $\begin{array}{c}-.217 \\
(-0.98)\end{array}$ & $\begin{array}{c}-.253 \\
(-1.17)\end{array}$ & $\begin{array}{c}-.261 \\
(-1.19)\end{array}$ & $\begin{array}{c}-.135 \\
(-0.63)\end{array}$ & $\begin{array}{c}-.061 \\
(-0.29)\end{array}$ & $\begin{array}{c}-.053 \\
(-0.24)\end{array}$ & $\begin{array}{c}-.021 \\
(-0.09)\end{array}$ & $\begin{array}{c}.131 \\
(0.57)\end{array}$ & $\begin{array}{c}.095 \\
(0.50)\end{array}$ & $\begin{array}{c}.059 \\
(0.55)\end{array}$ & $\begin{array}{c}.001 \\
(0.01)\end{array}$ & $\begin{array}{c}.090 \\
(1.14)\end{array}$ & $\begin{array}{c}.036 \\
(0.52)\end{array}$ & $\begin{array}{c}-.001 \\
(-0.02)\end{array}$ & $\begin{array}{c}.053 \\
(0.71)\end{array}$ & $\begin{array}{c}.030 \\
(0.45)\end{array}$ & $\begin{array}{c}.051 \\
(0.48)\end{array}$ \\
\hline Services & $\begin{array}{l}.052 \\
(0.53)\end{array}$ & $\begin{array}{l}-.013 \\
(-0.14)\end{array}$ & $\begin{array}{l}-.058 \\
(-0.66)\end{array}$ & $\begin{array}{l}.009 \\
(0.10)\end{array}$ & $\begin{array}{l}.023 \\
(0.25)\end{array}$ & $\begin{array}{l}.012 \\
(0.16)\end{array}$ & $\begin{array}{l}.075 \\
(1.06)\end{array}$ & $\begin{array}{l}.062 \\
(0.84)\end{array}$ & $\begin{array}{l}.067 \\
(0.68)\end{array}$ & $\begin{array}{l}-.001 \\
(-0.01)\end{array}$ & $\begin{array}{l}-.005 \\
(-0.11)\end{array}$ & $\begin{array}{l}.035 \\
(0.94)\end{array}$ & $\begin{array}{l}.047 \\
(1.33)\end{array}$ & $\begin{array}{l}.069 \\
(2.00)\end{array}$ & $\begin{array}{l}.065 \\
(2.04)\end{array}$ & $\begin{array}{l}.051 \\
(1.72)\end{array}$ & $\begin{array}{l}.051 \\
(1.49)\end{array}$ & $\begin{array}{l}.029 \\
(0.69)\end{array}$ \\
\hline $\begin{array}{l}\text { Fixed-short-term } \\
\text { contract }\end{array}$ & $\begin{array}{l}.118 \\
(1.46)\end{array}$ & $\begin{array}{c}.011 \\
(0.16)\end{array}$ & $\begin{array}{c}.026 \\
(0.40)\end{array}$ & $\begin{array}{l}.018 \\
(0.29)\end{array}$ & $\begin{array}{c}.003 \\
(0.05)\end{array}$ & $\begin{array}{c}-.002 \\
(-0.03)\end{array}$ & $\begin{array}{c}.006 \\
(0.08)\end{array}$ & $\begin{array}{c}-.030 \\
(-0.41)\end{array}$ & $\begin{array}{l}-.023 \\
(-0.29)\end{array}$ & $\begin{array}{l}-.121 \\
(-1.12)\end{array}$ & $\begin{array}{l}-.073 \\
(-0.85)\end{array}$ & $\begin{array}{c}-.071 \\
(-1.05)\end{array}$ & $\begin{array}{c}-.069 \\
(-1.27)\end{array}$ & $\begin{array}{c}-.065 \\
(-1.17)\end{array}$ & $\begin{array}{l}-.020 \\
(-0.35)\end{array}$ & $\begin{array}{l}-.026 \\
(-0.49)\end{array}$ & $\begin{array}{c}-.042 \\
(-0.84)\end{array}$ & $\begin{array}{l}-.066 \\
(-1.17)\end{array}$ \\
\hline $\begin{array}{l}\text { Other type of } \\
\text { contract }\end{array}$ & $\begin{array}{l}-.369 \\
(-2.46)\end{array}$ & $\begin{array}{l}-.332 \\
(-2.04)\end{array}$ & $\begin{array}{l}-.241 \\
(-1.55)\end{array}$ & $\begin{array}{l}-.257 \\
(-1.66)\end{array}$ & $\begin{array}{l}-.147 \\
(-1.01)\end{array}$ & $\begin{array}{l}-.071 \\
(-0.57)\end{array}$ & $\begin{array}{l}-.048 \\
(-0.47)\end{array}$ & $\begin{array}{l}-.056 \\
(-0.64)\end{array}$ & $\begin{array}{l}-.168 \\
(-2.05)\end{array}$ & $\begin{array}{l}-.319 \\
(-2.87)\end{array}$ & $\begin{array}{l}-.306 \\
(-3.94)\end{array}$ & $\begin{array}{l}-.254 \\
(-4.04)\end{array}$ & $\begin{array}{l}-.246 \\
(-3.98)\end{array}$ & $\begin{array}{l}-.219 \\
(-3.91)\end{array}$ & $\begin{array}{c}-.157 \\
(-3.75)\end{array}$ & $\begin{array}{l}-.212 \\
(-5.73)\end{array}$ & $\begin{array}{l}-.214 \\
(-5.44)\end{array}$ & $\begin{array}{l}-.247 \\
(-4.03)\end{array}$ \\
\hline Constant & & $\begin{array}{c}2.230 \\
(17.66)\end{array}$ & $\begin{array}{c}2.319 \\
(17.41)\end{array}$ & $\begin{array}{c}2.33 \\
(17.29)\end{array}$ & & $\begin{array}{c}2.370 \\
(19.74)\end{array}$ & & $\begin{array}{c}2.495 \\
(21.30)\end{array}$ & $\begin{array}{l}2.579 \\
(18.60)\end{array}$ & $\begin{array}{c}1.904 \\
(19.35)\end{array}$ & $\begin{array}{c}2.067 \\
(22.91)\end{array}$ & $\begin{array}{l}-.026 \\
(-0.96)\end{array}$ & $\begin{array}{c}2.192 \\
(41.80)\end{array}$ & $\begin{array}{c}2.30 \\
(38.49)\end{array}$ & $\begin{array}{c}2.325 \\
(37.30)\end{array}$ & $\begin{array}{c}2.48 \\
(36.38)\end{array}$ & $\begin{array}{c}2.579 \\
(36.32)\end{array}$ & $\begin{array}{c}2.667 \\
(33.20)\end{array}$ \\
\hline $\begin{array}{l}\mathrm{R}^{2} \\
\text { Observations }\end{array}$ & .446 & .343 & .285 & .252 & $\begin{array}{l}.236 \\
288\end{array}$ & .235 & .240 & .269 & .330 & .286 & .229 & .219 & .209 & $\begin{array}{l}.201 \\
742\end{array}$ & .205 & .202 & .201 & .207 \\
\hline
\end{tabular}

\section{t-values in brackets.}

The specifications include dummies by firm size, macro-region and occupational category. Complete tables available upon request. 